\title{
Evolution of the Lower Permian Rochlitz volcanic system, Eastern Germany: reconstruction of an intra-continental supereruption
}

\author{
Marcel Hübner ${ }^{1}$ (1) $\cdot$ Christoph Breitkreuz ${ }^{1}$ - Alexander Repstock ${ }^{2} \cdot$ Bernhard Schulz $^{3} \cdot$ Anna Pietranik $^{4}$. \\ Manuel Lapp ${ }^{2} \cdot$ Franziska Heuer $^{5}$
}

Received: 8 September 2020 / Accepted: 20 May 2021 / Published online: 14 July 2021

(c) The Author(s) 2021

\begin{abstract}
Extensional tectonics in the Late Paleozoic Central Europe was accompanied by rift magmatism that triggered voluminous intracontinental caldera-forming eruptions. Among these, the Lower Permian Rochlitz Volcanic System (RVS) in the North Saxon Volcanic Complex (Eastern Germany, Saxony) represents a supereruption (VEI 8, estimated volume of $1056 \mathrm{~km}^{3}$ ) of monotonous rhyolites followed by monotonous intermediates. Mapping, petrography, whole-rock geochemistry along with mineral chemistry and oxygen isotopes in zircon display its complex eruption history and magma evolution. Crystal-rich (>35 vol\%), rhyolitic Rochlitz- $\alpha$ Ignimbrite with strong to moderate welding compaction erupted in the climactic stage after reheating of the magma by basaltic injections. Due to magma mixing, low-volume trachydacitic-to-rhyolitic Rochlitz- $\beta$ Ignimbrite succeeded, characterized by high Ti and $\mathrm{Zr}$-values and zircon with mantle $\delta^{18} \mathrm{O}$. Randomly oriented, sub-horizontally bedded fiamme, and NW-SE striking subvolcanic bodies and faults suggest pyroclastic fountaining along NW-SE-oriented fissures as the dominant eruption style. Intrusion of the Leisnig and the Grimma Laccoliths caused resurgence of the Rochlitz caldera forming several peripheral subbasins. In the post-climactic stage, these were filled with lava complexes, ignimbrites and alluvial to lacustrine sediments. Significant $\mathrm{Nb}$ and $\mathrm{Ta}$ anomalies and high $\mathrm{Nb} / \mathrm{Ta}$ ratios (11.8-17.9) display a high degree of crustal contamination for the melts of the RVS. Based on homogenous petrographic and geochemical composition along with a narrow range of $\delta^{18} \mathrm{O}$ in zircon Rochlitz- $\alpha$ Ignimbrite were classified as monotonous rhyolites. For the Rochlitz- $\beta$ Ignimbrites, underplating and mixing with basic melts are indicated by $\mathrm{Mg}$-rich annite-siderophyllite and $\delta^{18} \mathrm{O}<6.0$ in zircon. The wide spectrum of $\delta^{18} \mathrm{O}$ on zircon suggests an incomplete mixing process during the formation of monotonous intermediates in the RVS.
\end{abstract}

Keywords Monotonous rhyolites $\cdot$ Monotonous intermediates $\cdot$ Magma mixing $\cdot$ Ti-in-biotite thermobarometer $\cdot \delta^{18} \mathrm{O}$ in zircon · VEI 8 fissure eruption

Marcel Hübner

marcel.huebner017@gmail.com

1 Institute of Geology, TU Bergakademie Freiberg, Bernhard-von-Cotta-Str. 2, 09599 Freiberg, Germany

2 Saxon State Office for Environment, Agriculture and Geology, Department of Geology, Halsbrücker Straße 31a, 09599 Freiberg, Germany

3 Institute of Mineralogy, TU Bergakademie Freiberg, Brennhausgasse 14, 09599 Freiberg, Germany

4 Institute of Geological Science, University of Wrocław, Plac Uniwersytecki 1, 50-137 Wrocław, Poland

5 Museum of Natural Science, Leibniz Institute for Research on Evolution and Biodiversity, Invalidenstraße 43, 10115 Berlin, Germany

\section{Introduction}

Eruptions forming voluminous crystal-rich ignimbrites are often related to reheating of crystal mush in the magma reservoir; underplating/injection of basic melts causes magma mingling, mixing and homogenization (Smith 1979; Bachmann et al. 2002; Bachmann and Bergantz 2004; Christiansen 2005; Folkes et al. 2011). This may result in the formation of monotonous intermediates known from many subduction-related settings (Hildreth 1981; Huber et al. 2012; Bachmann and Huber 2016; Kaiser et al. 2017). In these magmatic systems, melt extraction may result in zoned crystal-poor rhyolitic magma batches (Bachmann and Bergantz 2008a). Watts et al. (2016) reported on numerous supereruptions leading to high-volume, crystal-rich rhyolitic 
monotonous ignimbrites which display a limited variation in whole-rock geochemistry and open-system magmatic processes with a complex evolution (Cooper and Wilson 2014).

The late to post-orogenic phase of the Variscan Orogen in central Europe features many silica-rich, high volume volcanic complexes with large, crystal-rich ignimbrite sheets, associated with lava complexes and subvolcanic units (Timmerman 2008; Repstock et al. 2018). Among these volcanic complexes, studies have been carried out on the Ora caldera complex in northern Italy (Willcock et al. 2013; Willcock and Cas 2014), the Donnersberg Formation in the Saar-Nahe Basin in south-western Germany (Lorenz and Haneke 2004; Boy et al. 2012) and the Northeast German Large Igneous Province (Benek et al. 1996; Paulick and Breitkreuz 2005; Breitkreuz et al. 2007; Geißler et al. 2008). Further examples are the Halle Volcanic Complex in central Germany (Breitkreuz et al. 2018; Fig. 1) and the Intra-Sudetic and North Sudetic Basins in Poland and Czech Republic (Awdankiewicz 1999).

In the Saxothuringian domain of the Variscides, numerous Late Paleozoic volcanic centers are located (Fig. 1). In the Erzgebirge Block, the Mid-Carboniferous Tharandt Forest Caldera (Benek 1980) and Teplice-Altenberg Volcanic Complex (e.g., Breiter et al. 2001; Breiter et al. 2012; Breitkreuz et al. 2021; Mlčoch and Skácelová 2010; Walther et al. 2016, Casas García et al. 2019) evolved. At the Carboniferous-Permian boundary further volcanic activity led to formation of the Meißen Volcanic (Benek et al. 1977), the Chemnitz Basin with its petrified forest (Schneider et al. 2012), and the North Saxon Volcanic Complex.

The North Saxon Volcanic Complex (NSVC) is located east of the city of Leipzig (Eastern Germany, Saxony) and extends over $54 \times 54 \mathrm{~km}$. It contains at least two large nested caldera systems (Fig. 2), the Wurzen Volcanic System (WVS, Repstock et al. 2018) and the Rochlitz Volcanic System (RVS; Eigenfeld 1978). Like in the San Juan Mountains (Lipman 1976, 1997), partial erosion of the NSVC enabled deep insight in climactic and post-climactic pyroclastic deposits and subvolcanic bodies. Partial erosion also removed caldera-outflow facies for both, WVS and RVS.

It has to be noted that the WVS is one of the first examples of monotonous intermediates recorded to have formed in an intra-continental setting.

A spectrum of eruption styles has been reported for the climactic phase of large caldera systems. On the one hand, an initial eruption column accompanied by Plinian fallout may collapse, forming voluminous ignimbrites (e.g., Taupo Volcanic Zone, Wilson et al. 2006; Minoan eruption of the Santorini Volcanic Field, Johnston et al. 2014; Valles Caldera, Cook et al. 2016a, b). On the other hand, pyroclastic fountaining (Branney and Kokelaar 2002) from fissures or ring dykes is the dominant eruption style of many large caldera systems (Long Valley Caldera, Hildreth and Mahood 1986; San Juan Mountains, Bachmann et al. 2000; Western Snake River Plain, Branney et al. 2008; Ora Formation, Willcock et al. 2013). Pyroclastic fountaining along

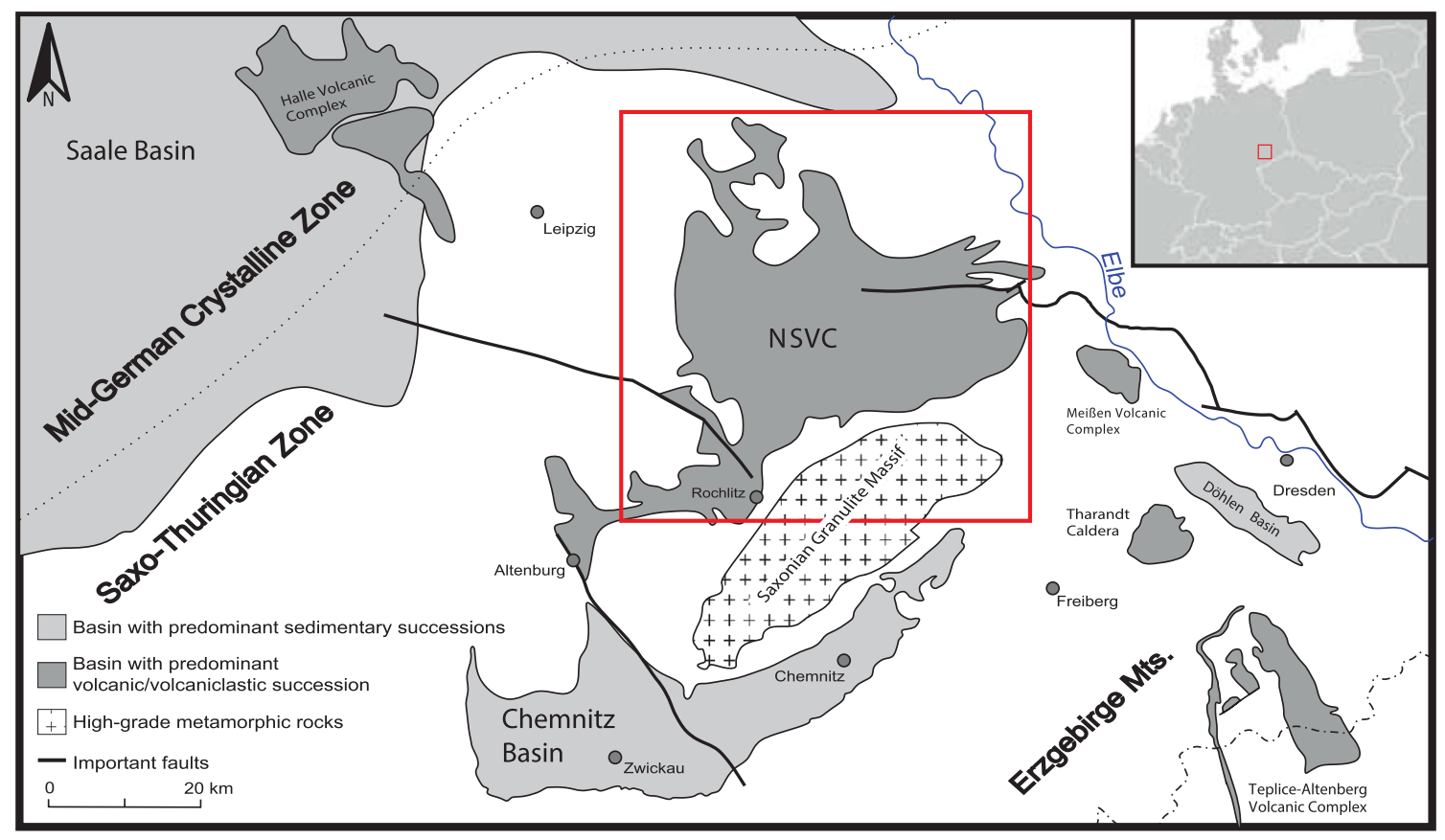

Fig. 1 Simplified geological map of Late Palaeozoic basins and volcanic centers in Saxony and neighboring areas (Modified after Hoffmann et al. 2013) 

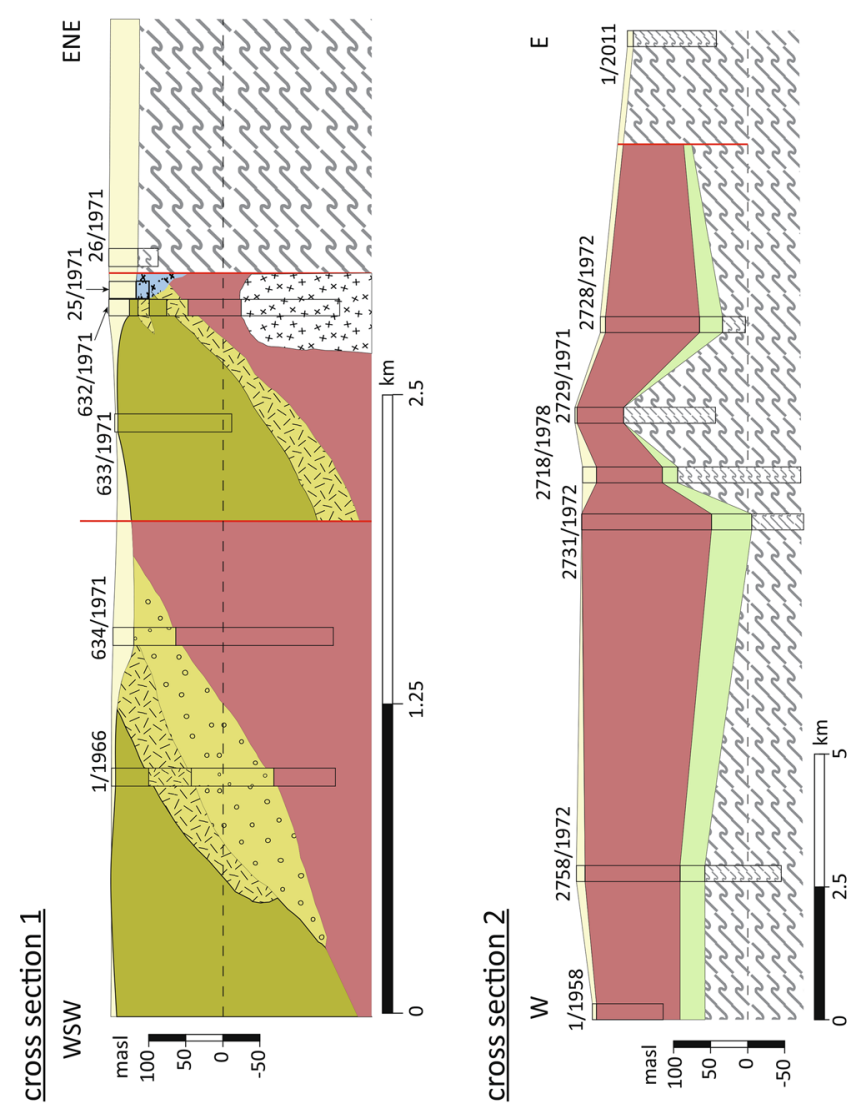

$z$

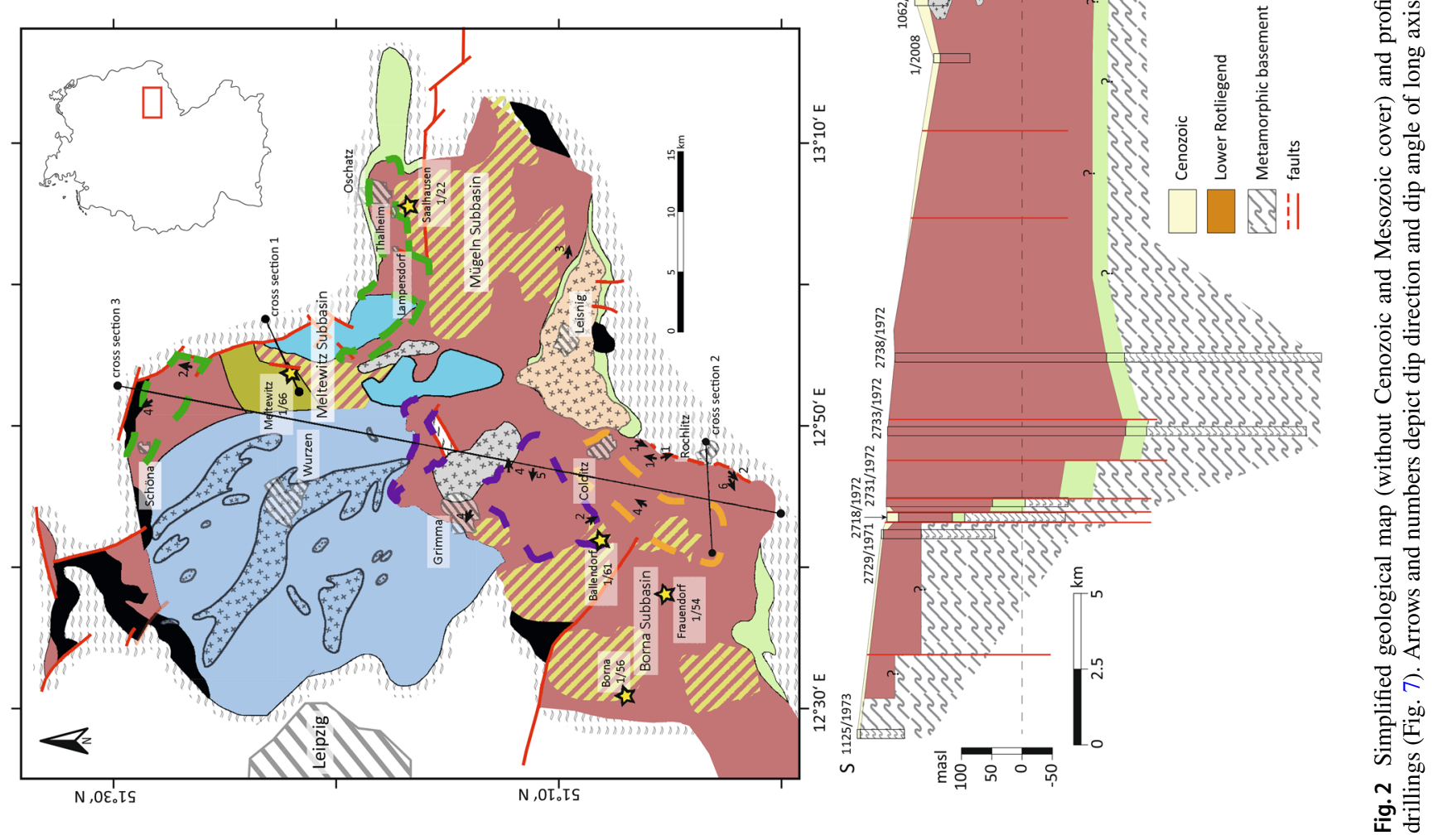


NW-SE-striking fissures was the predominant eruption style assumed for the WVS (Repstock et al. 2018).

For the RVS, we combine data from previous studies with new data on physical volcanology and petrography from outcrop and drillings (aspect ratio and orientation of fiamme, granulometry, maximum particle size). New whole-rock geochemistry, biotite chemistry and $\delta^{18} \mathrm{O}$ on zircon are provided. The results obtained will be used to reconstruct the evolution of one of the largest eruptions in central Europe during the Late Paleozoic. This study depicts several eruption stages of the RVS, and the magma evolution of a supervolcano in an intra-continental setting.

\section{Geological setting}

The NSVC, situated east of Leipzig (Figs. 1, 2), covers an area of c. $1600 \mathrm{~km}^{2}$ and represents a nested caldera complex hosting the large Rochlitz and the Wurzen Volcanic Systems, with diameters of 54 and $26 \mathrm{~km}$, respectively (Figs. 1, 2; Röllig 1969, 1976; Eigenfeld 1978; Repstock et al. 2018). Although northern Saxony is largely covered by Quaternary (peri-) glacial deposits, local outcrops, many quarries and hundreds of exploration drillings allow for good insight into the distribution of NSVC lithotypes. First data on wholerock geochemistry of NSVC units were published by Wetzel et al. (1995), characterizing the volcanic rocks as subalkaline to slightly alkaline with a rhyolitic to slightly trachytic composition. Radiometric ages, ranging from 300 to $287 \mathrm{Ma}$, were published by Wendt et al. (1995) and Hoffmann et al. (2013).

According to Walter (2006) the volcaniclastic and epiclastic succession of the NSVC can be subdivided into four formations (Fig. 3). The lowermost Kohren Formation overlies metamorphic basement rocks and comprises alluvial to fluvial sand- and siltstones as well as debris flow deposits intercalated with basic to silica-rich pyroclastics and lavas (Walter 2006). Biostratigraphy suggests a deposition age close to the Permian-Carboniferous boundary (Barthel et al. 1976). Hoffmann et al. (2013) obtained a radiometric age of $298.3 \pm 9.1 \mathrm{Ma}(\mathrm{U} / \mathrm{Pb}$ SHRIMP on zircons) for a tuff at the base of the formation. In previous studies (e.g., Hohl and Wilsdorf 1966; Walter 2006, 2012), the Leisnig Porphyry, a complex silica-rich magmatic body of $16 \mathrm{~km}$ in E-W-extension and up to $220 \mathrm{~m}$ in thickness, has been interpreted as a lava flow belonging to the Kohren Fm. (Figs. 2, 3). Within the Leisnig unit, Hohl and Wilsdorf (1966) distinguished a "normal" facies dominated by feldspar phenocrysts from biotite- and quartz-dominated domains (Fig. 5). In the center of the Leisnig Porphyry, two dyke complexes, partially in

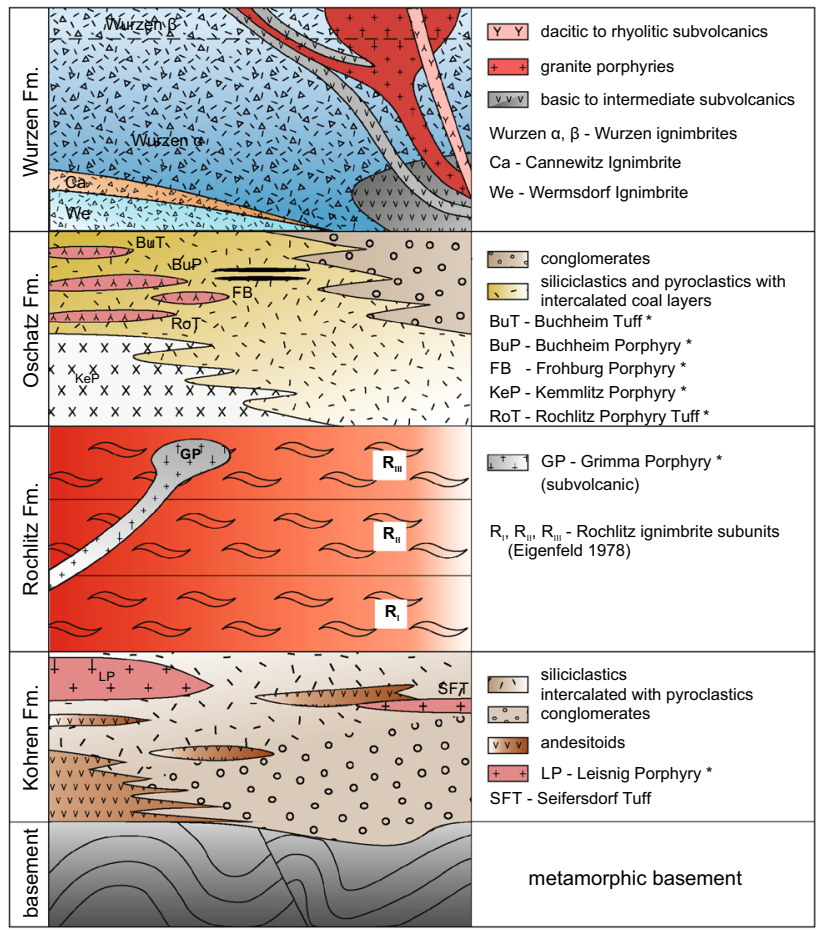

Fig. 3 Lithostratigraphic chart of the NSVC; based on Walter (2006, 2012), Hoffmann et al. (2013), Repstock et al. (2018). *Nomenclature after Walter (2012)

pitchstone facies with large lithophysae (Götze et al. 2020), were recognized (Hohl and Wilsdorf 1966).

The Rochlitz Fm. consists of various welded ignimbrites, with a minimum thickness of $400 \mathrm{~m}$ (Röllig 1976), overlying both the Kohren Fm. and the Variscan basement (greywacke, schist, phyllite, quartzite and gneiss; Figs. 2, 3). Variation in the modal mineral content has been applied to distinguish four depositional units $\left(\mathrm{R}_{\mathrm{I}}\right.$, $\mathrm{R}_{\mathrm{II}}, \mathrm{R}_{\mathrm{III}}, \mathrm{R}_{\mathrm{N}}$; Röllig et al. 1970, Eigenfeld 1978). This subdivision was supported by Wetzel et al. (1995) using geochemical data. Based on joint measurements, Eigenfeld (1978) allocated each unit as an individual cooling unit. Unit $\mathrm{R}_{\mathrm{I}}$ has been dated with SHRIMP $\mathrm{U} / \mathrm{Pb}$ on zircon at $294.4 \pm 1.8 \mathrm{Ma}$ (Hoffmann et al. 2013). These authors emphasized, the analyzed unit yielded no inherited zircon.

No caldera outflow facies, equivalent to $R_{I}$ to $R_{I I I}$, has been recognized in the neighboring Saale and Döhlen Basins (Fig. 1; Ehling and Gebhardt 2012; Reichel and Schneider 2012). However, according to Fischer (1991) and Schneider et al. (2012), a prominent pyroclastic flow deposit of the Chemnitz Basin (Fig. 1), the partly vitrophyric Planitz Ignimbrite (296.6 $\pm 3.0 \mathrm{Ma}$, Hoffmann et al. 2013), represents a distal deposit of the RVS. However, Repstock et al. (2019) 
showed some significant differences in mineral textures and biotite composition between the RVS ignimbrites and the Planitz Ignimbrite.

The following Oschatz Fm. consists of a terrestrial sedimentary succession intercalated by low-volume pyroclastic deposits, lavas and subvolcanics (Fig. 3; e.g., Walter 2006) accommodated in three subbasins: (1) the Mügeln Subbasin in the east comprises a large lava complex (Kemmlitz Porphyry, Götze et al. 2017) and various terrestrial sediments (Saalhausen Beds, Börtewitz Lake; Walter 2010); (2) the Meltewitz Subbasin in the northeast consists of conglomerates and local ignimbrites, e.g., the Dornreichenbach Ignimbrite; (3) the Borna Subbasin in the southwest contains small-volume volcanics, e.g., the Frohburg Ignimbrite and alternating tuffs and ignimbrites of the Buchheim Porphyry. Kuhn (1968) interpreted the latter as flow-foliated lava. According to Anegg (1970) and Wetzel et al. (1995), in outcrops near Grimma, lava and subvolcanic units show extrusion over (Gattersburg Porphyry) or intrusion into (Grimma Porphyry) the Rochlitz Ignimbrites.

The youngest NSVC unit is the Wurzen Fm. comprising $\geq 199 \mathrm{~km}^{3}$ of welded ignimbrites and subvolcanics (Röllig 1969; Repstock et al. 2018). Like with the Rochlitz Ignimbrites, these caldera fill ignimbrites are extremely crystal-rich (up to $58 \mathrm{vol} \%$ ), including 1-6 vol\% clino- and orthopyroxene (e.g., Röllig 1969; Röllig et al. 1970; Repstock et al. 2018). No caldera outflow facies has been detected, so far. Whole-rock geochemistry reveals a trend from silica-rich to intermediate composition (Repstock et al. 2018). The WVS ignimbrites were intruded by porphyritic granite magma forming extended NW-SE-oriented subvolcanic bodies that contain pyroxene phenocrysts.

The WVS evolution is characterized by magma mingling and mixing due to underplating and reheating by basaltic melts (Repstock et al. 2018). Applying different radiometric methods, Wendt et al. (1995) established an age of $287 \pm 3$ Ma for the WVS ignimbrites and Hoffmann et al. (2013) determined a SHRIMP U/Pb age on zircon of $289.3 \pm 4.1$ Ma for a rhyolitic porphyritic dyke cutting through the granite porphyry.

Local hydrothermal activity and widespread Mesozoic and Cenozoic subtropical weathering led to intense alteration in central Europe (Dill et al. 2015). In places, the NSVC volcanics were kaolinized up to $40 \mathrm{~m}$ depth (e.g., Kemmlitz Porphyry, Fig. 6; Schwerdtner and Störr 1983; Walter 1991). At the "Rochlitzer Berg" (for location see Online Resource Table 1), alteration formed an outstanding facies of the Rochlitz Ignimbrite called Rochlitz Porphyry Tuff with high porosity, a prominent eutaxitic texture and a bright red colour (Fig. 4A). It is utilized as dimension stone for more than 1000 years.

Table 1 Old and new nomenclature, lithostratigraphy and interpretation of RVS units

\begin{tabular}{|c|c|c|c|c|c|c|}
\hline \multicolumn{4}{|c|}{ Former studies (after Röllig, 1969, Anegg 1970, Eigenfeld 1978) } & \multicolumn{3}{|l|}{ This study } \\
\hline Formation & $\begin{array}{l}\text { Unit (old } \\
\text { nomenclature) }\end{array}$ & $\begin{array}{l}\text { Petrographical classification and } \\
\text { characteristics }\end{array}$ & Interpretation & $\begin{array}{l}\text { Unit (new } \\
\text { nomenclature) }\end{array}$ & $\begin{array}{l}\text { Petrographical and geochemical } \\
\text { characteristics }\end{array}$ & Interpretation \\
\hline \multirow{6}{*}{ 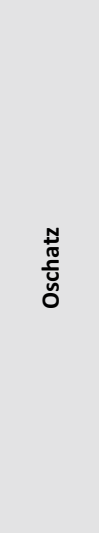 } & $\begin{array}{l}\text { Dornreichenbach } \\
\text { Porphyry }\end{array}$ & $\begin{array}{l}\text { Rhyolitic ignimbrite, } \\
\text { most qtz in NSVC }\end{array}$ & Local ignimbrite & $\begin{array}{l}\text { Dornreichenbach } \\
\text { Ignimbrite }\end{array}$ & $\begin{array}{l}\text { Greyish crystal-and fiamme-rich } \\
\text { ignimbrite, highest } \mathrm{SiO}_{2} \text { and lowest } \mathrm{Zr} \text { and } \\
\mathrm{Ti}, \mathrm{Nb} / \mathrm{Ta} \text { and } \mathrm{La} / \mathrm{Nb} \text { in } \mathrm{NSVC} \text {, pronounced } \\
\text { negative } \mathrm{Eu} \text { and } \mathrm{Ti} \text { anomaly }\end{array}$ & $\begin{array}{l}\text { Small eruption of highly } \\
\text { differentiated ignimbrite in the } \\
\text { Meltewitz Subbasin }\end{array}$ \\
\hline & $\begin{array}{l}\text { Buchheim } \\
\text { Porphyry }\end{array}$ & $\begin{array}{l}\text { Rhyolitic ignimbrite, } \\
\text { weakly welded }\end{array}$ & Lava complex & Buchheim Volcanics & $\begin{array}{l}\text { Intercalation of tuffs and strongly welded, } \\
\text { trachydacitic to rhyolitic ignimbrites }\end{array}$ & $\begin{array}{l}\text { Alternating strata of fallout tuffs } \\
\text { and ignimbrites }\end{array}$ \\
\hline & $\begin{array}{l}\text { Frohburg } \\
\text { Porphyry }\end{array}$ & $\begin{array}{l}\text { Rhyolitic ignimbrite } \\
\text { less fiamme, weakly welded, }\end{array}$ & Local ignimbrite & Frohburg Ignimbrite & $\begin{array}{l}\text { Porous, weakly welded, crystal-poor, } \\
\text { rhyolitic ignimbrite, pronounced negative } \\
\text { Eu and Ti anomaly, HREE elevated }\end{array}$ & $\begin{array}{l}\text { Eruption of highly differentiated } \\
\text { ignimbrite in the Borna Subbasin }\end{array}$ \\
\hline & Grimma Porphyry & Phenorhyolite, flow foliation & Subvolcanic & Grimma Laccolith & $\begin{array}{l}\text { Microgranite, trachydacitic to rhyolititc, } \\
\text { smoky qtz dominant, coarsely porphyritic }\end{array}$ & Laccolith complex with apophyses \\
\hline & Leisnig Porphyry & Subvolcanic body & Lava complex & Leisnig Laccolith & Microgranite, flow foliation & Laccolith complex in central RVS \\
\hline & $\begin{array}{l}\text { Gattersburg } \\
\text { Porphyry }\end{array}$ & Phenoryholite, flow foliation & $\begin{array}{l}\text { lava from a } \\
\text { stratovolcano/ } \\
\text { subvolcanic }\end{array}$ & $\begin{array}{l}\text { Rochlitz- } \alpha \text { and }-\beta \\
\text { Ignimbrites }\end{array}$ & $\begin{array}{l}\text { Altered ignimbrite around Grimma } \\
\text { Laccolith, similar petrographic features } \\
\text { and geochemical composition as Rochlitz } \\
\text { Ignimbrites }\end{array}$ & $\begin{array}{l}\text { Altered facies of Rochlitz } \\
\text { Ignimbrites around Grimma } \\
\text { Laccolith }\end{array}$ \\
\hline \multirow{3}{*}{ 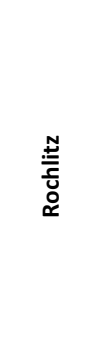 } & $\mathrm{R}_{\mathrm{N}}$ & $\begin{array}{l}\text { Rhyolitic ignimbrite, partly Kfs } \\
\text { dominant, reddish fiamme }\end{array}$ & $\begin{array}{l}\text { Distinct ignimbrites of } \\
\text { Rochlitz eruption }\end{array}$ & Rochlitz N Ignimbrite & $\begin{array}{l}\text { Positive } \mathrm{Pb} \text { anomaly, } \mathrm{Mg} \text { - and } \mathrm{Mn} \text {-poor } \\
\text { biotites, K-rich sanidine }\end{array}$ & $\begin{array}{l}\text { Final ignimbrites of the Rochlitz } \\
\text { eruption }\end{array}$ \\
\hline & $\mathrm{R}_{\text {III }}$ & $\begin{array}{l}\text { Rhyolitic ignimbrite, only ignimbrite } \\
\text { with pyroxene }\end{array}$ & $\begin{array}{l}\text { Third eruption of } \\
\text { Rochlitz Ignimbrite }\end{array}$ & Rochlitz- $\beta$ Ignimbrite & $\begin{array}{l}\text { Trachydacitic to rhyolitc ignimbrites of } \\
\text { greyish color, high } \mathrm{Ti} \text { and } \mathrm{Zr} \text {, less } \\
\text { pronounced negative Eu anomaly, Mg-rich } \\
\text { and } \mathrm{Mn} \text {-poor biotites, several zircon with } \\
\delta^{18} \mathrm{O}<6\end{array}$ & $\begin{array}{l}\text { Monotonous intermediate } \\
\text { ignimbrites }\end{array}$ \\
\hline & $\mathrm{R}_{\|}$ & $\begin{array}{l}\text { Rhyolitic ignimbrite, more crystals } \\
\text { than } R_{l} \text {, less fiamme } \\
\text { Rhyolitic ignimbrite }\end{array}$ & $\begin{array}{l}\text { Second eruption of } \\
\text { Rochlitz Ignimbrite } \\
\text { First eruption of } \\
\text { Rochlitz Ignimbrite }\end{array}$ & Rochlitz- $\alpha$ Ignimbrite & $\begin{array}{l}\text { Rhyolitic ignimbrites, moderate } \mathrm{Ti} \text { and } \mathrm{Zr} \\
\text { values, high } \mathrm{Mn} \text { in biotites and narrow } \\
\text { range in } \delta^{18} \mathrm{O} \text { in zircon compared to } \\
\text { Rochlitz- } \beta\end{array}$ & $\begin{array}{l}\text { Main eruption of the RVS, } \\
\text { monotonous rhyolite }\end{array}$ \\
\hline
\end{tabular}


Fig. 4 Rock slabs of RVS samples. A Porphyritic ignimbrite (Rochlitz Porphyry Tuff) from "Rochlitzer Berg"; B fine grained phreatic dyke crosscutting Rochlitz- $\alpha$ Ignimbrite at "Rochlitzer Berg" in NW-SEdirection; C Part of a $40 \mathrm{~cm}$ thick rhyolitic flow-foliated sill intercalated in the "Lastauer Tuff" (locality 23/5/13/2 in Online Resource Table 1) representing a possible early intrusion phase of the Leisnig Laccolith
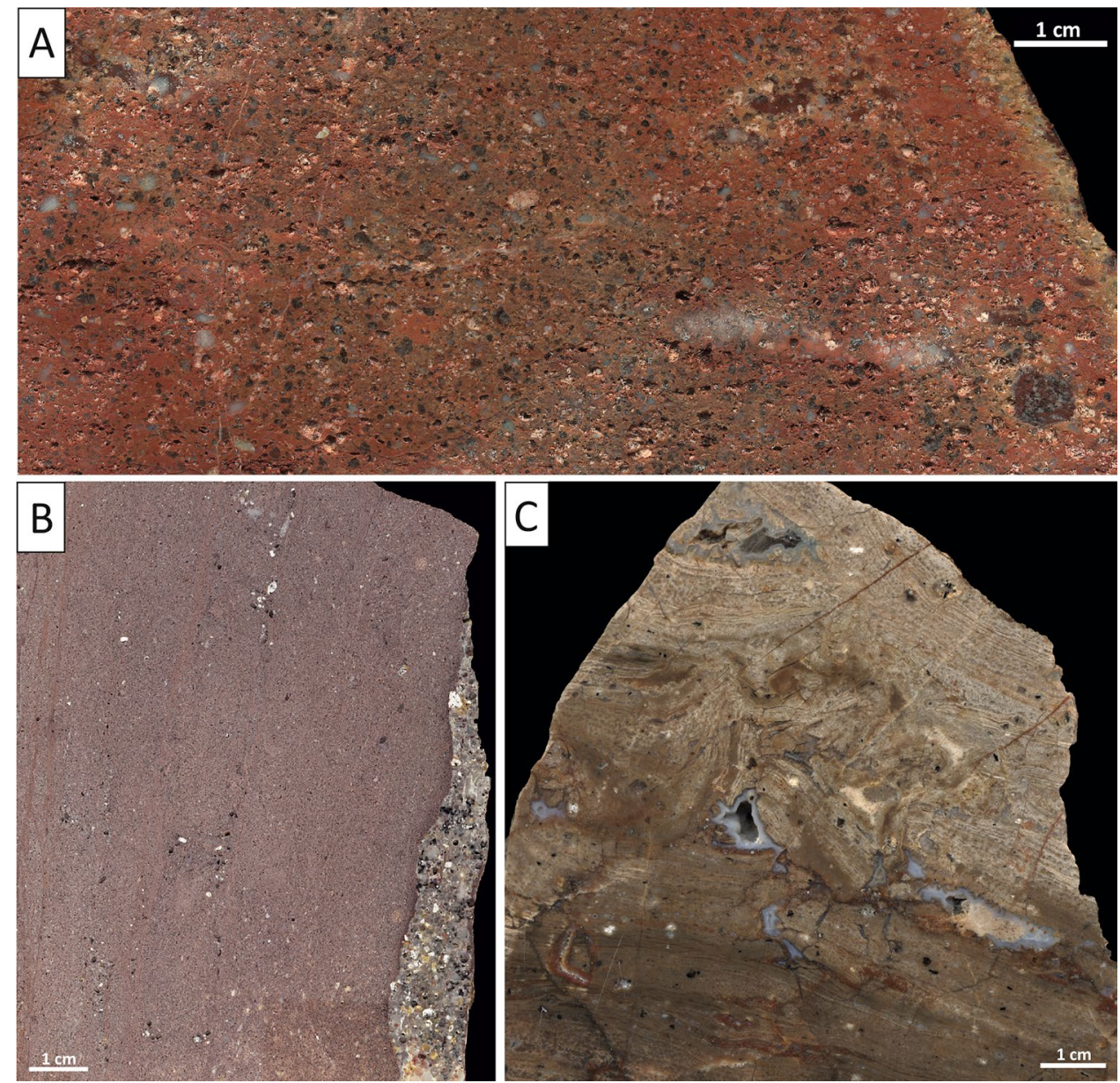

\section{Methods}

Samples were taken from 69 outcrops and quarries, in addition with 16 samples from drill cores (Online Resource Fig. 1). Besides, 49 drilling reports have been considered. For establishing the emplacement mode of the subvolcanic bodies, detailed mapping and evaluation of drilling descriptions were carried out. Petrographic analyses were accomplished on 106 thin sections. Phenocryst mode and maximum particle size (MPS, four measurements per thin section, Online Resource Table 3) on minerals and fiamme were measured by applying ZeissAxioVision 4.9 and JMicrovison software. Long-axis strike and dip of fiamme were determined for constraining the eruption style and vent locations (Fig. 2; Online Resource Table 2). The aspect ratio of fiamme (ratio of height and length) has been calculated and classified according to Quane and Russell (2005).

77 geochemical bulk-rock analyses on whole-rock samples (0.5-2 kg per sample, Online Resource Table 4) from the RVS volcanic rocks were carried out at Bureau Veritas in Vancouver (Canada). Analyses on major element oxides, minor and trace elements were measured with inductively coupled plasma mass spectrometry (ICP-MS), and the elements $\mathrm{Mo}, \mathrm{Cu}, \mathrm{Pb}, \mathrm{Zn}, \mathrm{Ni}, \mathrm{As}, \mathrm{Cd}, \mathrm{Sb}, \mathrm{Bi}, \mathrm{Ag}$, $\mathrm{Au}, \mathrm{Hg}, \mathrm{Tl}$ and Se by inductively coupled plasma atomic emission spectroscopy (ICP-AES).

Composition of biotite (Online Resource Table 6) and feldspar (Online Resource Table 7) was investigated using at a JEOL RX8900d wd/ed combined micro analyzer at the Institute of Material Science, TU Bergakademie Freiberg. The applied spectral lines, standards and counting times are presented in Online Resource Table 5. Additional analyses were performed at the Berlin Museum of Natural History-Leibniz Institute for Evolution and Biodiversity Science, using a JEOL JXA-8500F field emission electron probe micro analyzer. Operating conditions for both were set to $15 \mathrm{keV}$ and $20 \mathrm{nA}$ with a beam diameter up to $2 \mu \mathrm{m}$. Analyses at the EPMA in Berlin were calibrated on Smithsonian international mineral standards. For spectral lines, standards and peak counting times on each analyzed element see Online Resource Table 5.

Zircon crystals have been mechanically separated from samples using high-voltage pulse SelFrag in the Geological Institute of TU Freiberg. For concentration gravity separation was performed. The zircon was manually picked 
and mounted. The standard TEMORA II (one standard per three unknowns) was also mounted.

Oxygen isotopes have been quantified on zircon (Online Resource Table 8) at a SHRIMP II multi-collector ion microprobe at Micro-area Analysis Laboratory of PGINRI, Warsaw. The configuration of the instrument and applied analytical procedure were based on Ickert et al. (2008). The oxygen isotope data were corrected using the POXI MC software (P. Lanc). Oxygen isotope ratios are reported in standard per mille notation relative to Vienna Standard Mean Ocean Water.

\section{Results}

\section{Structural outline of the RVS caldera}

In the vicinity of the town of Rochlitz and at the southern margin of the Mügeln Subbasin, the Rochlitz Ignimbrites rest on Variscan basement with an erosional unconformity. The outline of the RVS is marked by andesitoids of the Kohren Fm. occurring at the northeastern and eastern margin as well as in the Borna Subbasin (Gläßer 1983; Fig. 2). Outcrops and drillings reveal that the RVS is bordered by subvertical faults in the N, NE and SW, which are assumed to have acted as volcanotectonic normal faults during caldera subsidence (Fig. 2). As depicted in profile 3 (Fig. 2), the southern part of the Rochlitz caldera is characterized by a piecemeal-like, intense block faulting (Branney and Kokelaar 1994).

Porphyritic laccoliths with granitic composition emplaced both in the central RVS and at its northeastern margin (Fig. 2). Emplacement of the laccoliths in the center led to a caldera resurgence forming several subbasin. The central laccoliths of the RVS strike NW-SE, like the subvolcanic bodies of the WVS (Repstock et al. 2018). A small block of the Variscan basement was uplifted in the central RVS forming a horst like structure (Fig. 2).

\section{Lithostratigraphic framework of the RVS}

Based on the new data set the classification of the Rochlitz Fm. had to be modified (see Table 1). Granulometric and geochemical data do not allow for a distinction between the subunits $\mathrm{R}_{\mathrm{I}}$ and $\mathrm{R}_{\mathrm{II}}$ (Figs. 9, 10). However, the new wholerock immobile trace element data $(\mathrm{Ti}, \mathrm{Zr}, \mathrm{P})$, and biotite geochemistry are helpful to differentiate $R_{I I I}$ and $R_{N}$ from $R_{I}$ and $R_{I I}$. Therefore, the units $R_{I}$ and $R_{I I}$ are grouped to the new unit Rochlitz- $\alpha$ and $R_{\text {III }}$ will be renamed as Rochlitz- $\beta$. The subunit $\mathrm{R}_{\mathrm{N}}$ will be renamed to Rochlitz-N for a coherent labeling. Following the geochemical data presented here, this sub-unit can be divided into the Schöna and Thalheim subtypes. Based on our textural investigation, a new nomenclature for some RVS volcanics and subvolcanics has been established (Table 1).

\section{Rochlitz ignimbrites}

In the southern part of the NSVC, a continuous belt of outand subcrops of the welded Rochlitz Ignimbrites occurs. The belt measures c. $54 \mathrm{~km}$ from the Borna Subbasin in the west to the Mügeln Subbasin in the east (Fig. 2) covering an area of c. $880 \mathrm{~km}^{2}$. In this belt, numerous exploration drillings ( $\geq 100 \mathrm{~m}$ deep) were drilled into the Rochlitz Ignimbrites, such as Borna 1/56 (146 m), Saalhausen 1/22 (224 m), and Ballendorf 1/61 (119 m; Fig. 7). Drilling Frauendorf 1/54 completely perforated the Rochlitz Fm. exposing 398.7 m thickness for the Rochlitz Ignimbrite (Fig. 7). Further drillings, which also document a thickness of the RVS ignimbrites up to $400 \mathrm{~m}$ were used to construct profiles depicted in Fig. 2. Besides, isolated outcrops and a few drillings at the northern and northeastern margin of the NSVC exhibit welded ignimbrites considered as Rochlitz Ignimbrites (Fig. 2; see also Röllig et al. 1970, Wetzel et al. 1995, Walter 2006). Fallout and surge deposits related to the Rochlitz Ignimbrites have not been observed in the NSVC (Table 1).

As depicted in Fig. 2, the lowermost unit Rochlitz- $\alpha$ shows the largest distribution, whereas Rochlitz- $\beta$ is restricted to an area in the northwest of Colditz. West of Oschatz and northeast of Wurzen (Fig. 2), Rochlitz Ignimbrites occur locally summarized as Rochlitz-N (Eigenfeld 1978). However, field relation and drillings do not expose transitions from Rochlitz- $\alpha$ to Rochlitz- $\beta$ Ignimbrites.

All Rochlitz Ignimbrite units comprise phenocrysts of plagioclase, alkali feldspar, quartz, biotite and pseudomorphs of chlorite after pyroxene (Online Resource Table 2). Contents of quartz, plagioclase and K-feldspar vary significantly within a single unit, however, the broad spectrum allows no differentiation between the units. As a consequence, a subdivision of RVS ignimbrites based on modal composition, as proposed by Eigenfeld (1978), cannot be maintained. The Rochlitz Ignimbrites have crystal contents between 35 and 47 vol\% (Online Resource Table 3). Maximum particle size (MPS) ranges between 2.0 and $4.5 \mathrm{~mm}$ for quartz and feldspar (Online Resource Table 3). Scarce lithics (granulites, sandstones and volcanic rocks) occur with a MPS of $1 \mathrm{~cm}$ (Fig. 8A-D). Frequently, small agglomorates of feldspar, quartz and Fe-Ti-minerals and micrographic intergrowth of quartz and biotite have been documented (Fig. 8E). The groundmass consists of a fine mosaic of quartz and K-feldspar. Typical characteristics of the Rochlitz Ignimbrites are a homogenous mineral and structural content, a strong to moderate welding compaction (Fig. 8H) and embayments on plagioclase and quartz (Fig. 8F, Online Resource Fig. 3A, B). Domains of partially devitrified vitrophyric Rochlitz- $\alpha$ 
with perlitic texture occur near Lastau (Fig. 8C), Ebersbach and Korpitzsch (Online Resource Table 1; Eigenfeld 1978, Jentsch 1979). In some areas of the central RVS, Rochlitz- $\alpha$ shows spherulites formed on the margin of fiamme (Fig. 8I).

The Rochlitz Ignimbrites are rich in fiamme with sizes up to $13 \mathrm{~cm}$ (Drilling Meltewitz 1/66, Figs. 7E, 8A-D). The aspect ratio of fiamme displays a eutaxitic texture (Fig. 8A-C, Online Resource Fig. 3C, D), ranging between II and V according to Quane and Russell (2005; Online Resource Table 2), with no significant vertical trend (Fig. 7E). Measurements on fiamme in natural outcrops and quarries reveal subhorizontal bedding and no preferred orientation of elongation on a regional scale (Fig. 2; Online Resource Table 2). The fiamme of Rochlitz-N are oxidized and hematized resulting in a reddish color (Fig. 8B), whereas the other units have black to green fiamme. Fiamme of Rochlitz- $\alpha$ display sometimes a porphyritic structure and have a low compaction (rank II-IV) compared to Rochlitz- $\beta$ fiamme with rank IV-V. The latter contains less phenocrysts.

\section{Post-climactic processes and rock units (Oschatz Fm.)}

The rhyolitic Leisnig Laccolith comprises three different lithotypes: a "normal" feldspar-dominated type and quartzor biotite-rich types (Fig. 5; Hohl and Wilsdorf 1966). All lithotypes have 70-90 vol\% of groundmass and MPS of quartz, feldspar and biotite phenocrysts is $3.0 \mathrm{~mm}, 5.0 \mathrm{~mm}$ and $2.5 \mathrm{~mm}$, respectively. Some domains are biotite-rich (3-6 vol\%), compared to the normal type with 1-3 vol\%. Throughout the accessible outcrops near the top margin of the laccolith, coherent facies with flow foliation and trains of vesicles are present. Flow foliation dips sub-horizontally to steeply eastward and southward, sub-parallel to the top margin of the laccolith (Fig. 5). Textures of carapace facies typical for rhyolitic lava flows, such as (ex-) glassy and pumice domains, spherulites and lithophysae, and, most important, brecciated domains (Manley and Fink 1987; Manley 1996) have not been observed.

Drillings close to Seifersdorf (Fig. 5) reveal a maximum thickness of $220 \mathrm{~m}$ for the Leisnig Laccolith and an offset

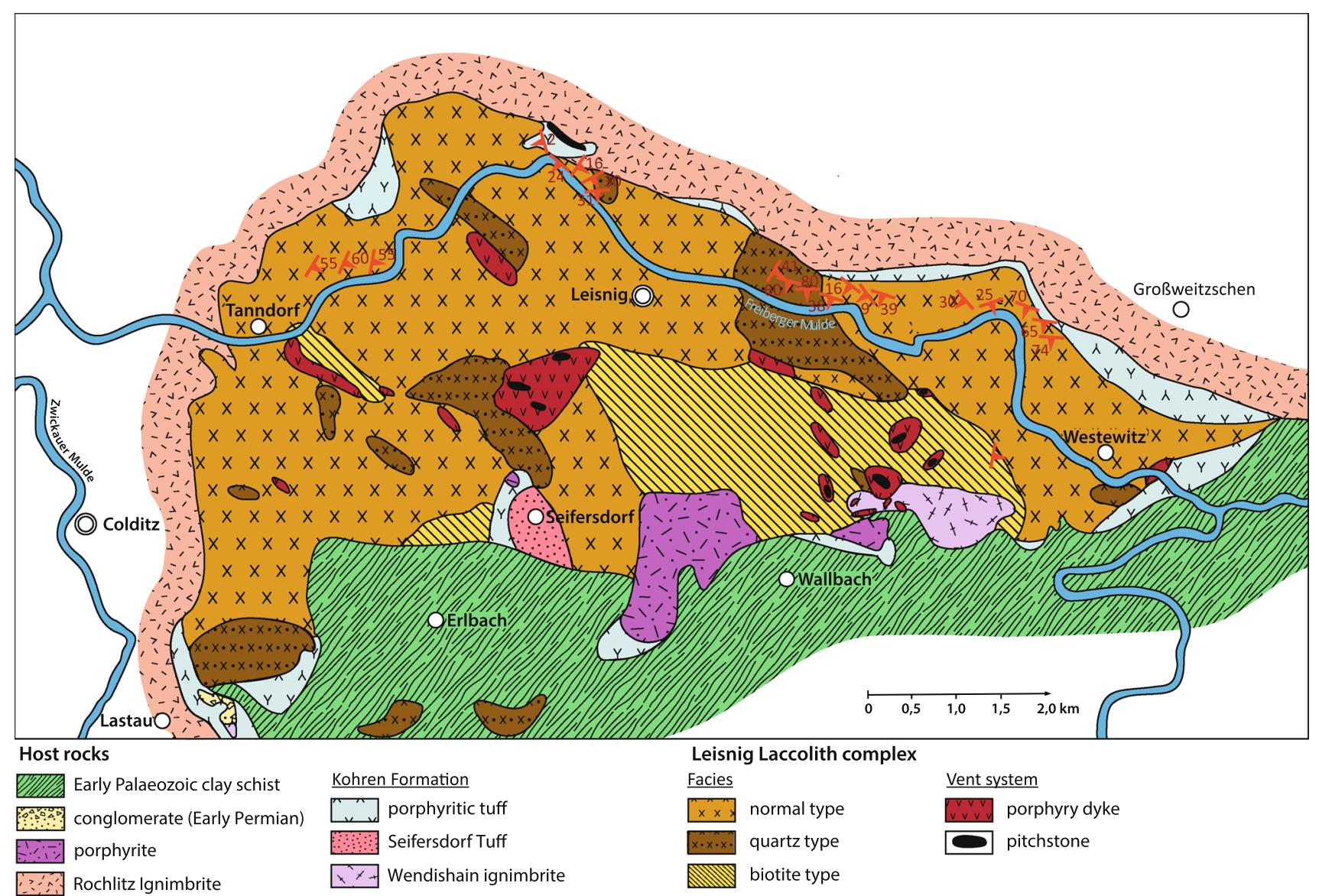

Fig. 5 Geological map (without Cenozoic cover) of the Leisnig Laccolith and neighboring units. Arrows and numbers represent dip direction and dip angle of flow foliation (modified after Hohl and Wilsdorf 1966) 


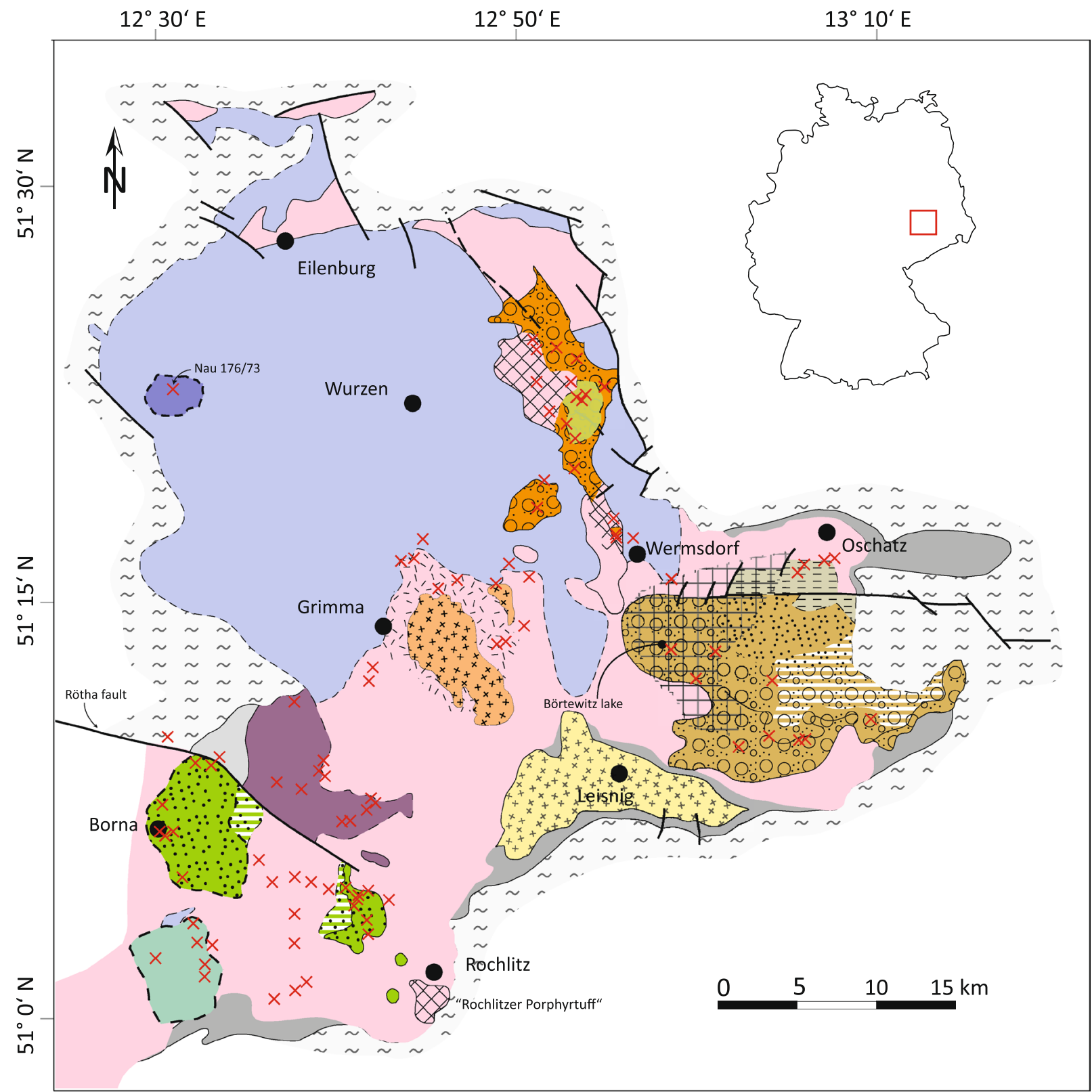

\section{Stratigraphic units}

Wurzen Formation Rochlitz Formation

Kohren Formation

$\approx$ y Variscan basement

\section{Oschatz Formation}

Borna Subbasin

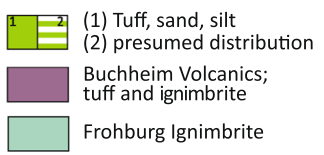

Frohburg Ignimbrite $+x^{++x}+x$
$x+y$ Grimma Laccolith

$\left[\begin{array}{c}x+x \\ +x+x \\ x+y\end{array}\right]$ Leisnig Laccolith

Central part of the NSVC$$
\text { Laccolith }
$$

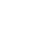

\section{$X \quad$ selected wells \\ - fault \\ - - - presumed distribution}

\begin{tabular}{ll} 
& Lithofacies \\
& alluvial fan fluvial, braided river \\
\hline$\equiv$ lacustrine & $\times$ kaolinized volcanic rocks
\end{tabular}

Fig. 6 Palaeogeographic map of the NSVC showing lithostratigraphic units and facies distribution within the Oschatz Formation (modified after Walter 2006) 
of its base of c. $180 \mathrm{~m}$. Furthermore, at the river bank of the Zwickau Mulde, south of Colditz, a $40 \mathrm{~cm}$ thick weakly porphyritic, rhyolitic sill intruded in the "Lastauer Tuff" at the base of Rochlitz- $\alpha$ (Pietzsch 1962; Fig. 4C; locality 23/5/13/2 in Online Resource Table 1).

NE-SW-striking phreatic dykes are crosscutting the Rochlitz Ignimbrites at Scheergrund and in an active quarry at "Rochlitzer Berg" (Fig. 4B; Online Resource Table 1). In summary, we interpret the Leisnig Porphyry as a laccolith complex emplaced into the tuffs and sediments of the Kohren Fm. below the Rochlitz Ignimbrites. The small sill near Lastau is, due to the similar geochemical composition and its position is considered as cogenetic to the emplacement of the Leisnig Laccolith. The formation of the phreatic dykes, crosscutting the Rochlitz Ignimbrites, may have been related to vapor explosions caused by the emplacement of the Leisnig Laccolith.

In the central RVS, the microgranitic Grimma Porphyry intruded in the Rochlitz Ignimbrites (Figs. 2, 3). The NW-SE-oriented subvolcanic body extends $8 \times 4 \mathrm{~km}$. The
Grimma Porphyry is characterized by an aplitic crystalline groundmass with large phenocrysts (up to $1.5 \mathrm{~cm}$ ) of smoky quartz dominating over altered feldspar and biotite. The phenocrysts make up 13-22 vol\% of bulk rock. At the eastern margin several sills (protolobes acc. to Hutton 2009) occur, depicting a laccolith structure for the Grimma Porphyry (Fig. 2 profile 1) leading to renaming the subvolcanic complex as Grimma Laccolith.

In the Borna Subbasin the post-Rochlitz succession comprises lava, pyroclastic rocks and clastic sediments (clayand sandstones, coal; Figs. 6, 7A, B). The slightly porphyritic Buchheim Volcanics are strongly welded ignimbrite (rank V, Quane and Russell 2005) with a maximum thickness of $120 \mathrm{~m}$ interbedded with fallout tuff. Its basal part is vitrophyric, in places. The Buchheim Ignimbrite has a high crystal content of 35-47 vol\% (Online Resource Table 3). The Frohburg Porphyry ( $50 \mathrm{~m}$ thickness) is an ignimbrite with eutaxitic texture. Its crystal content between 15 and $19 \mathrm{vol} \%$ is low compared to the other volcanics of the RVS.

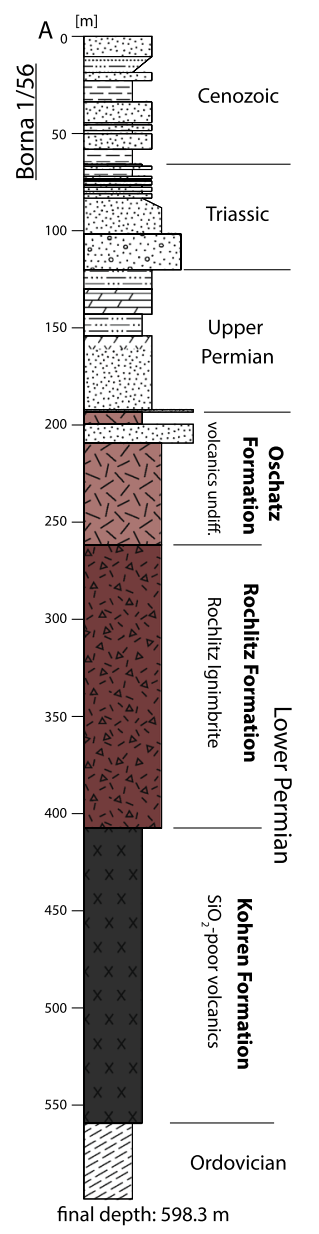

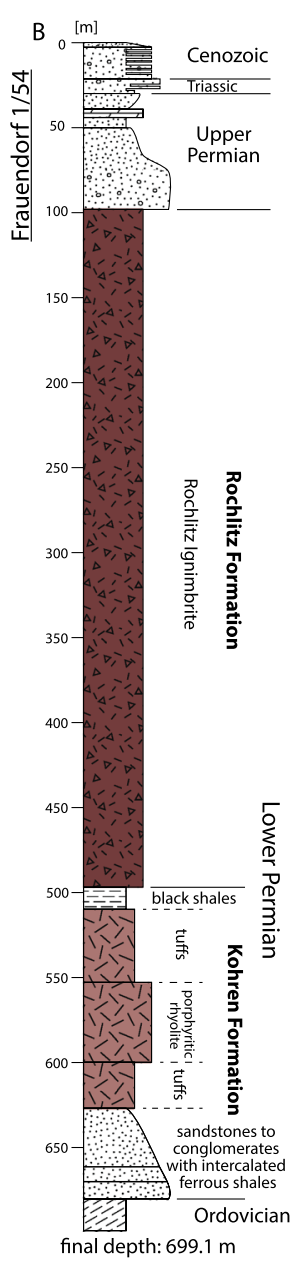

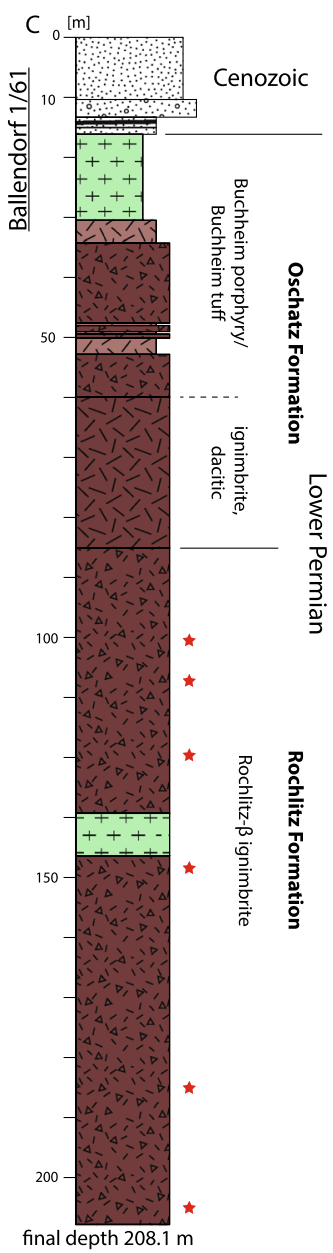

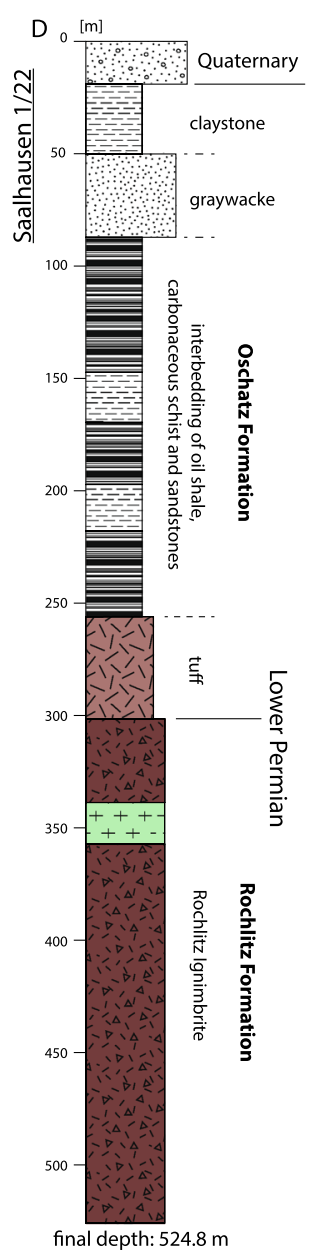

Fig. 7 Selected drillings (A Borna 1/56, B Frauendorf 1/54, C Ballendorf 1/61, D Saalhausen 1/22, E Meltewitz 1/66) displaying the Rochlitz Fm. as well as under- and overlying units. Colors comply with real colors. Green color display reducing alteration. Stars mark samples. (For location see Fig. 2) 
In contrast, the Mügeln Subbasin in the eastern RVS contains predominantly clastic sedimentary rocks (lacustrine to alluvial) with intercalations of tuffs and coals (Figs. 6, 7D, E). At the base of the succession, the at least $70 \mathrm{~m}$ thick Kemmlitz porphyritic rhyolite lava occurs (Fig. 6; Götze et al. 2017), which is actively being quarried for kaolinite (Schwerdtner and Störr 1983).

Furthermore, in the Meltewitz Subbasin between Schöna and Oschatz, Rochlitz- $\alpha$ Ignimbrite is overlain by a $110 \mathrm{~m}$ thick monomict, matrix- to clast-supported conglomerate (Fig. 7E). The porphyritic rhyolite lithics $(\varnothing \leq 7 \mathrm{~cm})$ may have been transported by debris flows from a lava dome (not exposed by drilling so far) which presumably formed along the RVS caldera margin. The conglomerate is overlain by a $57 \mathrm{~m}$ thick succession of fallout tuffs and reworked, in parts cross-bedded volcanoclastic deposits. The uppermost unit in drilling Meltewitz 1/66 (Fischer 1968) is the $45 \mathrm{~m}$ light gray Dornreichenbach Ignimbrite (Figs. 2, 7E) - a fiamme-and plagioclase-rich, moderately to weakly welded ignimbrite (rank III-IV, Quane and Russell 2005). The total crystal content of the ignimbrite varies from the lower part with 43 vol\% to the upper part with 33 vol\%. It comprises 24 vol\% of feldspar, 12 vol\% of quartz, and 1.3 vol\% of biotite with 5-9 vol\% of lithics. Since pyroxene and amphibole are rare, the Dornreichenbach Ignimbrite can clearly be distinguished from the nearby Wurzen ignimbrites (Röllig 1969).

\section{Whole-rock geochemistry}

The Rochlitz Ignimbrites can be classified as trachydacite and rhyolite using the TAS diagram (Fig. 10A). Rochlitz- $\alpha$ has a wide compositional range $\left(\mathrm{SiO}_{2}=66-81\right.$ wt $\%, \mathrm{Na}_{2} \mathrm{O}+\mathrm{K}_{2} \mathrm{O}=4.0-8.9$ wt $\%$ ). Rochlitz- $\beta$ reveals a slightly more trachydacitic composition $\left(\mathrm{SiO}_{2}=67-72 \mathrm{wt} \%\right.$, $\mathrm{Na}_{2} \mathrm{O}+\mathrm{K}_{2} \mathrm{O}=8.4-8.8 \mathrm{wt} \%$ ). The $\mathrm{Zr} / \mathrm{Ti}$ vs. $\mathrm{Nb} / \mathrm{Y}$ ratios support the classification based on major elements (Fig. 10C).

The Rochlitz Ignimbrites have a peraluminous character $(\mathrm{A} / \mathrm{CNK}=1.23-1.86)$ and show a subalkaline rhyolitic trend (Fig. 10A, B; Online Resource Table 1). Only ignimbrites of Rochlitz- $\beta$ show transition from subalkaline to alkaline affinity (Fig. 10A). The trachydacitic Rochlitz- $\beta$ has the highest $\mathrm{TiO}_{2}(0.32-0.55 \mathrm{wt} \%)$ and $\mathrm{Zr}$ values (266-386 ppm; Fig. 10D).

The Rochlitz-N occurrences near Oschatz and Wildschütz (Rochlitz-N type Thalheim) have relatively low $\mathrm{SiO}_{2}$-content (69-73 wt\%) and high values of $\mathrm{TiO}_{2}(0.26-0.36 \mathrm{wt} \%)$ and Zr (260-300 ppm), whereas the occurrences near Schöna and Lampersdorf (Rochlitz-N type Schöna) have high $\mathrm{SiO}_{2}$-content (75-78 wt $\left.\%\right)$, but low $\mathrm{TiO}_{2}(0.12 \mathrm{wt} \%)$ and $\mathrm{Zr}(115-150 \mathrm{ppm})$ concentrations (Fig. 10A, D) resulting in elevated $\mathrm{Zr} / \mathrm{Ti}$ ratios.

Whole-rock analyses of the Rochlitz Ignimbrites reveal a wide range of alteration (Fig. 9); however, Rochlitz- $\beta$ and Rochlitz-N display the least alteration (Online Resource Fig. 2). Ignimbrites of Rochlitz- $\beta$ seem to have a trachydacitic to rhyolitic composition before alteration started. In contrast, the original composition of Rochlitz-N ignimbrites was rhyolitic. The unaltered composition of Rochlitz- $\alpha$ is difficult to determine because of the different alterations as sericitization and K-feldspar crystallization. Considering the alteration index (Ishikawa et al., 1976) and the Carbonate-Chlorite-Pyrite Index (Gifkins et al., 2005) the predominant alteration of the volcanic rocks of the RVS is a hydrothermal sericitization and K-metasomatism leading to higher values of K (Fig. 9). The kaolinized samples of the "Rochlitzer Berg" experienced depletion of alkali metals $\left(<1 \mathrm{wt} \% \mathrm{Na}_{2} \mathrm{O}\right.$ and 2.5-3.4 wt $\% \mathrm{~K}_{2} \mathrm{O}$, Online Resource Table 4). The high silica contents are a consequence of this depletion.

Mantle-normalized trace element pattern shows a common trend with pronounced negative anomalies of $\mathrm{Ba}, \mathrm{Nb}$, Ta, Sr, P and Ti for all Rochlitz Ignimbrites (Fig. 11A). A small variation in $\mathrm{Zr}$ is evident. Rochlitz- $\beta$ shows less pronounced negative anomalies. Significant differences are depicted for $\mathrm{Pb}$ (Fig. 11A). Both Rochlitz-N domains, Schöna and Thalheim (Fig. 2), display positive $\mathrm{Pb}$ anomalies, whereas the main Rochlitz types are characterized by moderate negative anomalies. The low degree of alteration for Rochlitz- $\beta$ ignimbrites is confirmed by a significantly weak $\mathrm{Ba}$ anomaly. The strong variation observed for $\mathrm{Pb}$ and $\mathrm{Sr}$ in the Rochlitz subunits bears, at least in parts, magma genetic significance (e.g., Dostal et al. 1979; Vogel et al. 2004), in spite of the strong mobility of these elements during weathering and alteration of feldspar.

The chondrite-normalized REE patterns of the Rochlitz volcanics have a similar trend, with Rochlitz- $\beta$ showing a less pronounced negative Eu anomaly and lower HREE values (Fig. 11B). One sample of $\mathrm{R}_{\mathrm{II}}$ shows enriched HREE raising the mean values (Fig. 11B).

The subvolcanic Leisnig Laccolith has a chemical composition similar to the Rochlitz Ignimbrites (Fig. 10A, C). Mantle-normalized trace element pattern of the Leisnig Laccolith is similar to the Rochlitz Ignimbrites; however, with a less pronounced negative Eu-anomaly and overall depleted REE (Fig. 11D). The Nb/Ta ratios $(\sim 12.5)$ are lower than for the Rochlitz Ignimbrites ( 14.6) showing a slightly enhanced continental contamination (Green 1995).

Previous studies of Röllig et al. (1970) and Wetzel et al. (1995) depicted a lava surrounding the Grimma laccolith, the Gattersburg Porphyry. Our investigation revealed a pyroclastic eutaxitic texture and mineral content similar to the Rochlitz Ignimbrites (Online Resource Table 3). Similarities are also shown by the geochemical data and mantle-normalized trace element patterns (Figs. 10, 11).

Post-Rochlitz volcanic and subvolcanic units can be distinguished from the Rochlitz Ignimbrites using geochemical 

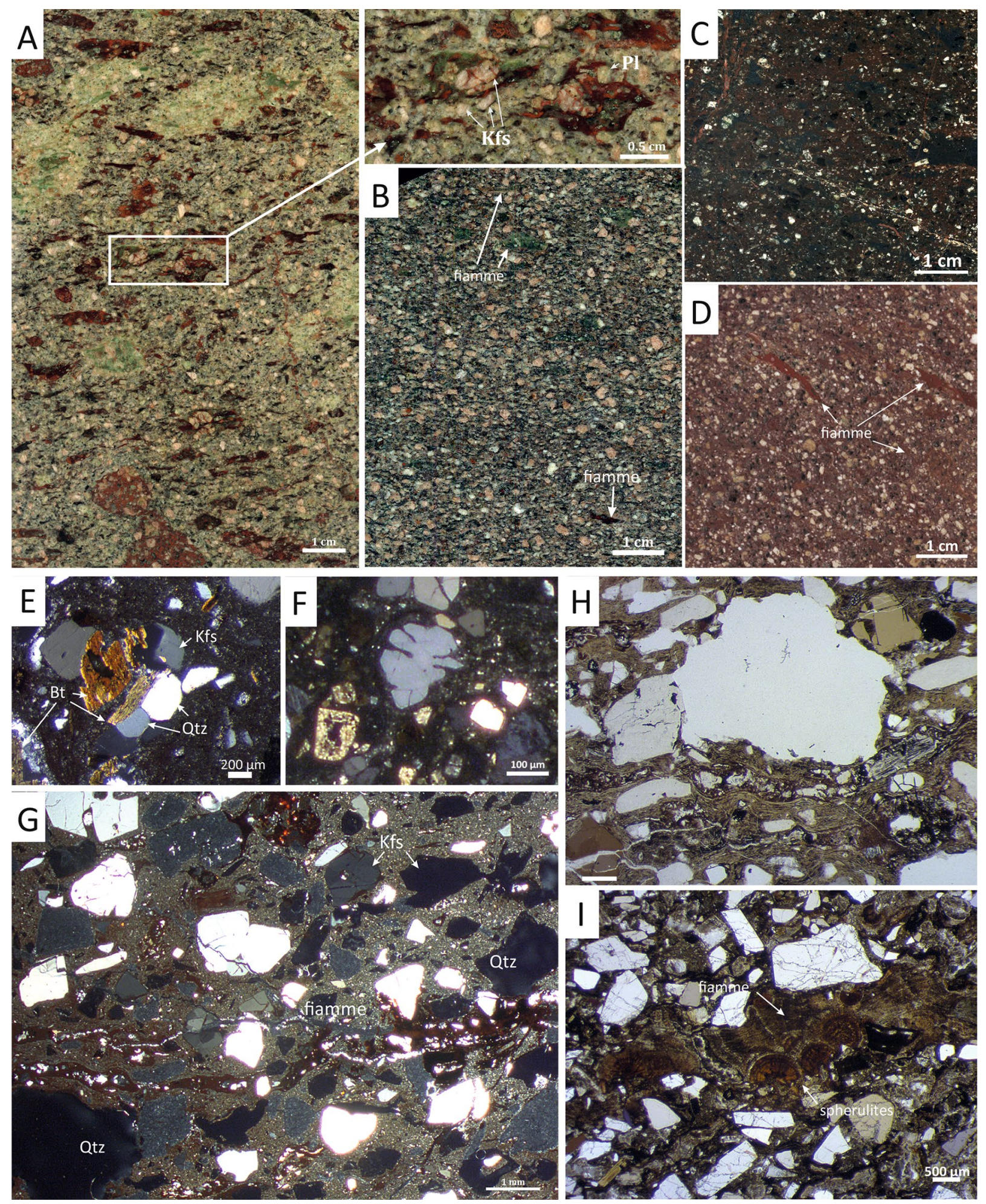

Fig. 8 Textural and petrographic features of Rochlitz Ignimbrites. A-D rock slabs, E-I thin sections (for location see Fig. 2). A Rochlitz- $\alpha$ Ignimbrite from drilling Meltewitz 1/66 with close-up of fiamme and eutaxitic texture. B Strongly welded Rochlitz- $\alpha$ Ignimbrite from the drilling Meltewitz 1/66 (Fig. 7E) displaying hematized and serizitized small fiamme (sample Mle 1/66 R10). C Devitrified Rochlitz- $\alpha$ from an outcrop near Lastau. D Rochlitz-N with typical hematized fiamme and eutaxitic texture. E Glomerophyric texture aggregates of Bt, Kfs and Qtz in Rochlitz- $\alpha$. F Quartz embayments in Rochlitz- $\beta$. G Rochlitz Porphyry Tuff from the "Rochlitzer Berg" with typical long and hematized fiamme and undulose extinction of Qtz. H Compaction structure in Rochlitz- $\alpha$. I Spherulites at the margin of fiamme in Rochlitz- $\alpha$ 
analyses. The Dornreichenbach Ignimbrite of the Meltewitz Subbasin shows the highest silica content within a narrow range (74-75 wt\%). The concentration of the alkalis $\left(\mathrm{Na}_{2} \mathrm{O}+\mathrm{K}_{2} \mathrm{O}\right)$ ranges between 6.3 and $9.0 \mathrm{wt} \%$, which presumably displays secondary depletion or enrichment (Fig. 10A; Online Resource Fig. 2). In contrast, the Frohburg Ignimbrite has the highest alkali concentration (up to $9.8 \mathrm{wt} \%$; Fig. 10A). It can be further distinguished from the Rochlitz Ignimbrites by relatively low $\mathrm{Nb} / \mathrm{Y}$ values (Online Resource Table 4). The significantly low $\mathrm{La} / \mathrm{Nb}$ and $\mathrm{Nb} /$ Ta ratios (Online Resource Table 4) allow discrimination of Dornreichenbach and Frohburg Ignimbrites from other RVS volcanics.

The Oschatz volcanics show mantle-normalized trace element patterns similar to the Rochlitz Ignimbrites. The Frohburg Ignimbrites have the highest HREE values in the NSVC. Similar REE and incompatible element pattern of the Grimma Laccolith and the Rochlitz- $\alpha$ Ignimbrite suggest a cogenetic magma evolution.

\section{Mineral chemistry and $\delta^{18} 0$ in zircon}

K-feldspar from Rochlitz- $\alpha$ and $-\beta$ Ignimbrites has sanidine signature, whereas Rochlitz-N contains ternary feldspar (Fig. 12, Online Resource Table 7). The composition of biotite in all Rochlitz Ignimbrite units ranges from siderophyllite to annite. Biotite of the Rochlitz- $\beta$ Ignimbrite covers the largest element distribution at the octahedral site $(\mathrm{Mg \#}$ from 24.4 to 52.7, Fig. 13A, Online Resource Table 6). Biotite in Rochlitz- $\alpha$ and Rochlitz-N Ignimbrites reveals a narrow Fe-rich compositional range, with $\mathrm{FeO}$-concentrations around 28.6 and 25.9 apfu for Rochlitz- $\alpha$ (Fig. 13A). All biotite of the RVS plots in the field of primary magmatic biotite (Fig. 13D). Along with iron, the manganese concentration is high in Rochlitz- $\alpha\left(\mathrm{R}_{\mathrm{II}}\right)$ biotite compared to those of other units (Fig. 13B). This may indicate crystal growth in more evolved melts, whereas the Mg-rich annite-siderophyllite from Rochlitz- $\beta$ crystallized in less evolved parts of the Rochlitz magma reservoir. The highest Ti-concentrations can be reported for the Mg-rich annite-siderophyllite of Rochlitz- $\beta$ (up to 10.4 wt\%; drilling Ballendorf 1/61; Fig. 13C, Online Resource Table 6).

Crystallization conditions in the Rochlitz magma reservoir can be explored by applying the Ti-in-biotite thermometry of Henry et al. (2005) and barometry of Wu and Chen (2015). This thermometer requires conditions of $X \mathrm{Mg}$ $\left(\mathrm{Mg} / \sum_{\mathrm{Mg}+\mathrm{Fe}}\right)$ in a range of 0.275 to 1.000 and Ti between 0.04 to 0.60 apfu (Henry et al. 2005). For Rochlitz- $\alpha$, a crystallization temperature of $732 \pm 30{ }^{\circ} \mathrm{C}$ and $768 \pm 30{ }^{\circ} \mathrm{C}$ for Rochlitz- $\beta$ have been obtained. The pressure can be estimated with $4 \pm 2 \mathrm{kbar}$. Assuming an average density of $2.8 \mathrm{~g} /$ $\mathrm{cm}^{3}$ for the Late Palaeozoic crust in this region, we estimate the crystallization depth at around $15 \pm 7 \mathrm{~km}$.
Oxygen isotopes in zircon from the Rochlitz- $\alpha$ and $-\beta$ Ignimbrites have a range from 3.87 to $9.61 \%$ (Online Resource Table 8, Fig. 14). Zircon of Rochlitz- $\beta$ (3.87-9.61\%o) is more heterogeneous than of Rochlitz- $\alpha(6.47-9.39 \%$ ). The zircon cores of Rochlitz- $\alpha$ have a narrow range between 6.71 and $7.17 \%$ with higher values in the rims (7.33-8.09). In contrast, zircon of Rochlitz- $\beta$ has higher $\delta^{18} \mathrm{O}$ in the cores than in the rims (Fig. 14).

\section{Discussion}

\section{Eruption style forming the RVS climactic ignimbrites}

Classic models of caldera evolution comprise thick mostly welded caldera fill, thin but widely distributed caldera outflow and ring dyke feeding systems (Lipman 1984; Cole et al. 2005). Thick ignimbrite packages may also form outside a caldera, as documented for the Bishop Tuff of the Long Valley Caldera (Hildreth 2004; Chamberlain et al. 2014), requiring a pre-existent deep topography. In pre-climactic stage of the RVS evolution (Fig. 16, stage 1; Table 2), andesitoid lava complexes of the Kohren Fm. formed close to the future RVS ring fault system (Figs. 2, 16; Gläßer 1983). On the other hand, Repstock et al. (2018) interpreted NW-SE-trending central subvolcanic bodies and dykes to represent major feeding fissures of the WVS (see also Branney et al. 2008 for the western Snake River system). Similarly, the Grimma Laccolith emplaced as a NW-SE-trending subvolcanic body in the central RVS. In the southeastern extension of it, the presence of the multi-vent Leisnig Laccolith complex gives further evidence for a fissure-shaped feeding system of RVS (Fig. 2). The Buchheim Volcanics overlying the Rochlitz- $\beta$ Ignimbrite in the west of the RVS represent a possible reactivation on the NW-SE-trending vent assumed for Rochlitz- $\beta$. In contrast to classic caldera with uniform piston subsidence, the Rochlitz caldera floor fragmented forming a piecemeal caldera with numerous vents according to Roche et al. (2000). Randomly oriented fiamme as in the Rochlitz Ignimbrites are typical for these eruptions (Scafell Caldera, Branney and Kokelaar 1994). Intra-caldera faults in the west and in the Mügeln and Meltewitz Subbasin (Fig. 2) support this interpretation.

During the climactic stage of the Rochlitz caldera (stage 2 phase 1), high volumes of crystal-rich, rhyolitic and strongly to moderately welded ignimbrites formed (Rochlitz- $\alpha$; Figs. 8D, 15; rank II-IV, Quane and Russell 2005). The high and homogenous welding compaction is a result of a fast deposition without significant breaks. No fallout or surge deposits, at the base or as intercalations in the Rochlitz Ignimbrites have been documented making Plinian eruption phases unlikely. Instead, we infer pyroclastic fountaining 
Fig. 9 Alteration after Gifkins et al. (2005). Chlorite-Carbonate-Pyrite Index (CCPI) vs. alteration index after Ishikawa et al. (1976) displaying alteration facies and trends. Boxes display unaltered rock composition. Legend is valid for Figs. 10, 12, and 13.

$\mathrm{AI}=\frac{100 *\left(\mathrm{MgO}+\mathrm{K}_{2} \mathrm{O}\right)}{\mathrm{MgO}+\mathrm{K}_{2} \mathrm{O}+\mathrm{CaO}+\mathrm{Na}_{2} \mathrm{O}} ;$

$\mathrm{CCPI}=\frac{100(\mathrm{FeO}+\mathrm{MgO})}{\mathrm{FeO}+\mathrm{MgO}+\mathrm{Na}_{2} \mathrm{O}+\mathrm{K}_{2} \mathrm{O}}$

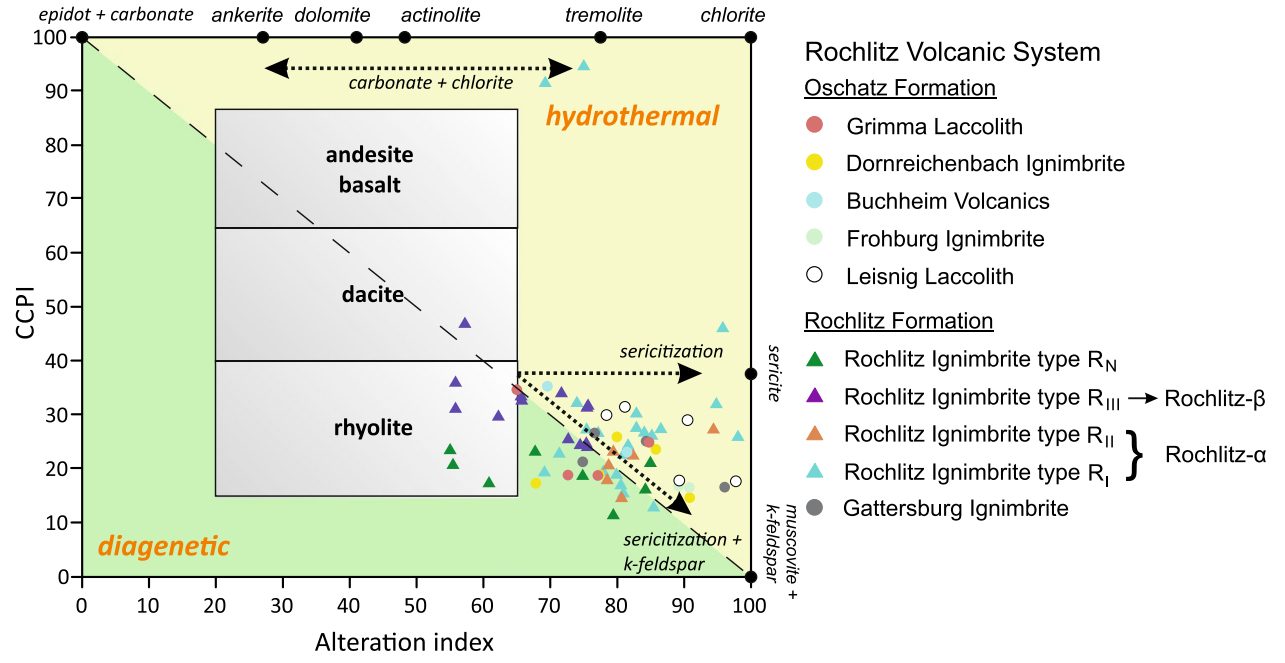

from NW-SE-trending fissures to be one of the dominant eruption styles.

Towards the termination of the climactic stage (stage 2 phase 2), the eruption of low-volume, crystal-rich, rhyolitic to trachydacitic magmas took place close to the western (Rochlitz- $\beta$ ) and northeastern margins (Rochlitz-N) of the Rochlitz caldera (Fig. 16). Scarcity of lithics in the Rochlitz system can be explained by rapid sealing of conduits by ascending magmas. It is also corroborated by the lack of inherited zircon in Rochlitz- $\alpha$ (Hoffmann et al. 2013).

The stratigraphic relation between Rochlitz- $\alpha$ and $-\beta$ is not well established. A clear contact between these subunits has not been documented in outcrops or drillings so far. Drilling Ballendorf 1/61 (Fig. 7C) displays c. $110 \mathrm{~m}$ of Rochlitz- $\beta$ Ignimbrite without reaching the base. The ignimbrite is followed directly by the Buchheim Volcanics of the Oschatz Formation. Other drilling reports in this area supply information about tuffs and metamorphic basement underlying Rochlitz- $\beta$, lacking Rochlitz- $\alpha$ Ignimbrite. These observations can be explained by an assumed paleo-topographic high in the Ballendorf area present during the deposition of Rochlitz- $\alpha$. Much of Rochlitz- $\beta$ Ignimbrite may have been eroded, leaving an erosional relict in the area northwest of Colditz (Fig. 2).

\section{Magnitude of RVS climactic eruption}

For magma volume calculation of the climactic Rochlitz- $\alpha$ Ignimbrite, a constant minimum thickness is estimated at $400 \mathrm{~m}$ (Fig. 7). The extension under the Wurzen Caldera is unknown, because no drilling reached the Rochlitz Ignimbrites underlying the Wurzen Ignimbrites. Assuming that the RVS ignimbrites completely underlie WVS $\left(1300 \mathrm{~km}^{2}\right)$, a volume of c. $533 \mathrm{~km}^{3}$ of preserved caldera-fill results. Confining the calculation to the continuous out- and subcrop belt in the southern NSVC $\left(880 \mathrm{~km}^{2}\right)$, a volume of $352 \mathrm{~km}^{3}$ can be assessed for the preserved caldera-fill ignimbrites. Sub recent calderas produced similar volumes of caldera fill, caldera outflow and co-ignimbritic ash deposits (Mason et al. 2004). Thus, using the conservative distribution, the total erupted volume of the RVS can be estimated as 1056 $\mathrm{km}^{3}$. According to Cook et al. (2016a, b), these calculations should be treated cautiously. Even this conservative volume estimation would result in a VEI of 8 (Newhall and Self 1982) rendering the Rochlitz event a supereruption (Rampino and Self 1992), comparable to the Permian Ora Fm. in northern Italy $\left(1290 \mathrm{~km}^{3}\right.$, Willcock et al. 2013). RVS would thus make one of the largest caldera systems in central Europe. Furthermore, the RVS is significantly larger than the WVS (c. $199 \mathrm{~km}^{3}$, Repstock et al. 2018) that formed a few million years later in the NSVC.

\section{Post-climactic evolution}

Presumably early in the post-climactic phase (stage 3 phase 1) the Leisnig Laccolith emplaced at the south-eastern margin of the RVS resulting in resurgence and formation of intra-caldera subbasins (Fig. 16; Fridrich et al. 1991; Kennedy et al. 2012). The magma intruded into volcaniclastic deposits of the Kohren Fm. underlying the Rochlitz Ignimbrites (among others the Wendishain ignimbrite; Fig. 5). The magma intruded into the still unconsolidated sediments. They can be considered as a suitable emplacement level between high strength metamorphic basement below and the thick welded Rochlitz Ignimbrites above (Awdankiewicz et al. 2004; Rocchi and Breitkreuz 2018). The dyke/ pitchstone domains located southwest of Leisnig and to the north of Wallbach represent feeding systems for the Leisnig Laccolith (Fig. 5). The two isolated outcrops of the quartzrich rhyolite in the basement south of Erlbach (Fig. 5) might be considered as additional feeding systems. This implies 

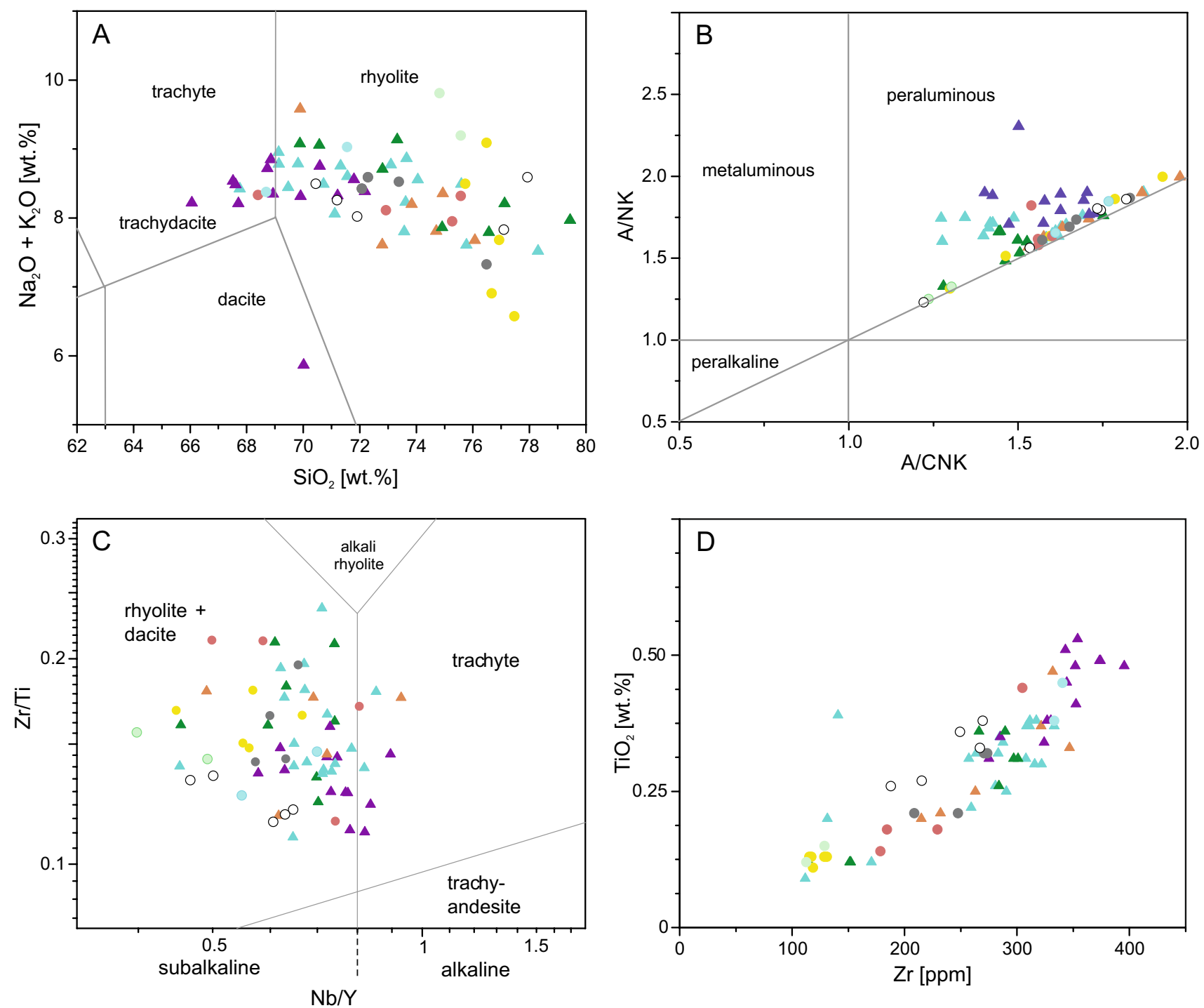

Fig. 10 Geochemical whole-rock data for volcanic and subvolcanic rocks of the RVS. A Total Alkali vs. Silica (TAS) diagram after Le Maitre et al. (1989). B $\mathrm{Al}_{2} \mathrm{O}_{3} / \mathrm{Na}_{2} \mathrm{O}+\mathrm{K}_{2} \mathrm{O}$ (ANK) vs. $\mathrm{Al}_{2} \mathrm{O}_{3}$ /

$\mathrm{CaO}+\mathrm{Na}_{2} \mathrm{O}+\mathrm{K}_{2} \mathrm{O}(\mathrm{ACNK}$; mol\%). C Zr/Ti vs. Nb/Y after Pearce et al. (1996). For data see Online Resource Table 4. D $\mathrm{TiO}_{2}$ vs. $\mathrm{Zr}$ diagram (for symbols see Fig. 9)

that the Leisnig Laccolith originally extended further to the south.

The presence of NE-SW-striking phreatic dykes crosscutting Rochlitz Ignimbrites at Scheergrund and in a quarry at Rochlitzer Berg (Fig. 4B; Online Resource Table 1) support the thesis of the Leisnig Laccolith. The dykes may have originated from phreatic explosions that occurred during the emplacement of the Leisnig Laccolith. The small sill at Lastau may represent an early intrusion phase of the Leisnig subvolcanic complex like the elongated, sub-horizontal bodies in the Henry Mtns. in Utah (Horsman et al. 2009). In drillings, tuff intercalations occur between Leisnig Laccolith protolobes which we consider as rafts of host rocks engulfed by rhyolitic melt. The new interpretation of the

Leisnig Porphyry as a laccolith implies emplacement after the climactic eruption of the Rochlitz Ignimbrites, and consequently it does not belong to the Kohren Fm. Apparently, after the climactic phase, magma ascended from the reservoir, leading to the resurgence of the caldera like in the Caetano Caldera and Valles Caldera (stage 3 phase 1; John et al. 2009; Kennedy et al. 2012).

The coarse crystalline Grimma Laccolith, which intruded the Rochlitz Ignimbrites, reveals textural and geochemical differences to the weakly crystalline Leisnig Laccolith suggesting an origin from different magma batches (Fig. 16). Due to the geometry of the Grimma Porphyry with protolobes (Hutton 2009), documented in various outcrops and drillings (Online Resource Fig. 2 profile 1), it can be also 

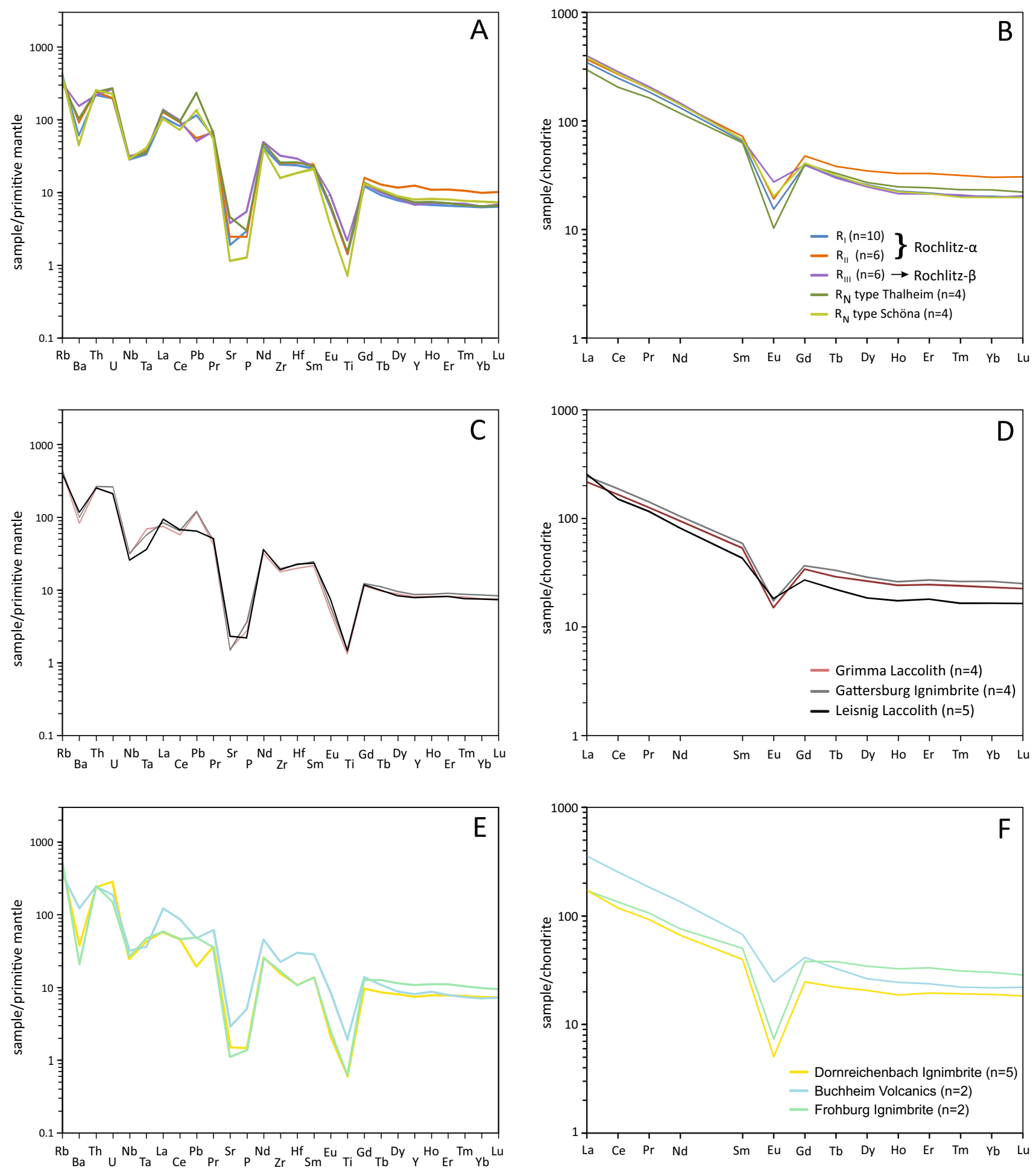

Fig. 11 Trace element and REE pattern of RVS rocks. A, C, E normalized to primitive mantle after Sun and McDonough (1989); B, D, F normalized to chondrite after McDonough and Sun (1995)

defined as a laccolith. The intrusion of subvolcanics at the end of the climactic phase of caldera eruptions is a typical feature of long-lasting magmatic systems (e.g., Chiaradia et al. 2009).
The monomict volcaniclastic conglomerate in the Meltewitz drilling presumably derived from a collapsed lava dome in the Meltewitz Subbasin indicates that post-climactic magmatism was also active at or near the RVS ring fault system 


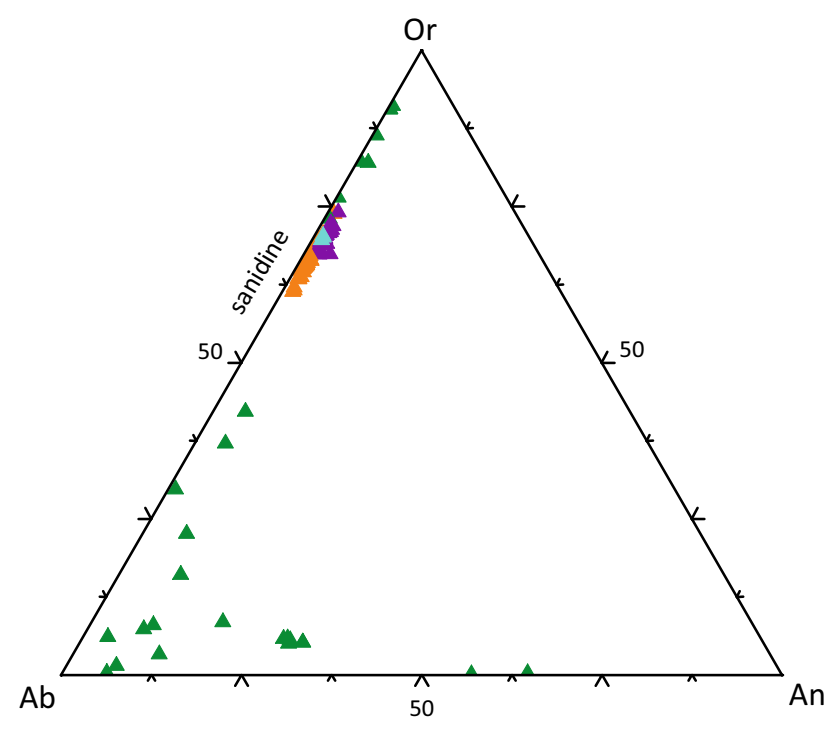

Fig. 12 Feldspar composition in Rochlitz Ignimbrites. Rochlitz- $\alpha$ and $-\beta$ only contain sanidine. The sanidine composition of Rochlitz-N is mainly K-rich. Plagioclase of Rochlitz-N contains up to $26 \%$ An (for symbols see Fig. 9)

(Fig. 2). Monotonous rhyolites are typical for open-system magma processes resulting in lava domes like in the Caetano Caldera in Nevada (Watts et al. 2016).

Due to the resurgence, the Borna, Mügeln and Meltewitz Subbasins formed in the moat depression around the resurgent dome(s) (stage 3 phase 1; Figs. 2, 16). The strongly welded Buchheim Ignimbrites of the Borna Subbasin reach a thickness of $120 \mathrm{~m}$ and host several intercalated tuffs, which presumably resulted from a series of smaller eruptions. Likewise, in the Meltewitz Subbasin, $110 \mathrm{~m}$ of conglomerates, overlain by $57 \mathrm{~m}$ of tuffs and by the Dornreichenbach Ignimbrite requires presence of a resurgencerelated paleo-topography. The effusion of the at least $5.6 \mathrm{~km}^{3}$ rhyolitic Kemmlitz Lava marks the earliest post-climactic volcanic activity in the Mügeln Subbasin (Figs. 6, 16; Götze et al. 2017). Above, $250 \mathrm{~m}$ thick alluvial to lacustrine sediments accumulated (Figs. 6, 16). Thus, we interpret that the emplacement of the Leisnig Laccolith (max. thickness of $220 \mathrm{~m}$ ) preceded the deposition in these subbasins (Fig. 16).

\section{Magmatic evolution}

The overall magmatic trend of the Rochlitz caldera-forming eruption is one from a homogenous, rhyolitic crystalrich melt (monotonous rhyolite) for Rochlitz- $\alpha$ to a typical monotonous intermediate composition for Rochlitz- $\beta$ (Figs. 14, 15; Hildreth 1981). Repstock et al. (2021) applied a range of geothermo- and barometers to constrain the depth of the WVS magma reservoirs between 15 and $40 \mathrm{~km}$. The biotite geothermo- and barometry presented here yielded a depth of $15 \mathrm{~km}$ for the magma chamber of the RVS. With an error of $\pm 7 \mathrm{~km}$ the uppermost magma chamber can be postulated with $\sim 8 \mathrm{~km}$, comparable to the estimates for the monotonous rhyolite Ongatiti ignimbrite (Cooper and Wilson 2014).

Reheating by underplating enables the eruption of crystal-rich magma is a widely accepted concept (Bachmann et al. 2002; Bachmann and Bergantz 2004; Huber et al. 2009, 2012). For the eruption of the voluminous rhyolitic and crystal-rich Rochlitz- $\alpha$ magma intense reheating had to occur (Fig. 16). In contrast to similar eruptions of crystalrich magmas (Ongatiti Ignimbrite, Cooper and Wilson 2014; WVS, Repstock et al. 2018) apparently magma mingling was not important for the RVS as suggested by lack of fiamme and minerals with basic composition. Instead, magma mixing is indicated by resorption textures in plagioclase and quartz in Rochlitz- $\beta$ Ignimbrite (Fig. 8F, Online Resource Fig. 3A, B) showing disequilibrium between magma and crystals (Patiño Douce and Johnston 1991; Matthews et al. 2012). Wetzel et al. (1995) already discussed magma mixing as the dominant process for RVS. Convection in the upper part of the magma chamber resulted in homogenization forming voluminous rhyolitic magma batches as it has been stated for the Nevada Volcanic Field (Henry and John 2013), the Ongatiti Ignimbrite (Cooper and Wilson 2014) and the Caetano Tuff (Watts et al. 2016). Due to the homogenous and distinct biotite composition (Fig. 13) and the narrow range in $\delta^{18} \mathrm{O}$ of zircon of Rochlitz- $\alpha$ (Fig. 14), these ignimbrites constitute large-volume monotonous rhyolites (Fig. 15).

The slightly more basic composition of the Rochlitz- $\beta$ Ignimbrite together with $\mathrm{Nb} / \mathrm{Ta}$ ratios up to $17 \mathrm{sug}$ gests magma mixing with underplating basic magma that resulted in a monotonous intermediate composition (Fig. 16; Green 1995; Bachmann and Bergantz 2008b; Huber et al. 2012). The significant negative Ti anomaly (Fig. 11) indicates fractionation of Fe-Ti-minerals like titanomagnetite and ilmenite. These minerals can be found in glomerocrysts, which are cumulates of a less evolved magma (e.g., Ellis et al. 2013). The pseudomorphs of pyroxene together with the absence of amphibole in RVS, indicate injection of $\mathrm{H}_{2} \mathrm{O}$-poor, basic magma. This is supported by low $\delta^{18} \mathrm{O}$ in some zircon rims. Due to the large heterogeneity of $\delta^{18} \mathrm{O}$ in the Rochlitz- $\beta$ zircon, it can be assumed, that the homogenization process, typical for monotonous intermediates, remained incomplete in RVS.

The high $\mathrm{Nb} / \mathrm{Ta}$ ratios (12.3-17.9, Rochlitz- $\alpha$; 12.8-17.3, Rochlitz- $\beta$ ) show a lower degree of differentiation (Green 1995; Ballouard et al. 2015) in contrast to the values of 9.1-10.3 and 9.8-9.9 of the post-climactic Dornreichenbach and Frohburg Ignimbrites, respectively (Online Resource Table 4). The lower $\mathrm{Nb} / \mathrm{Ta}$ ratio and a more pronounced negative Eu anomaly suggest a higher 

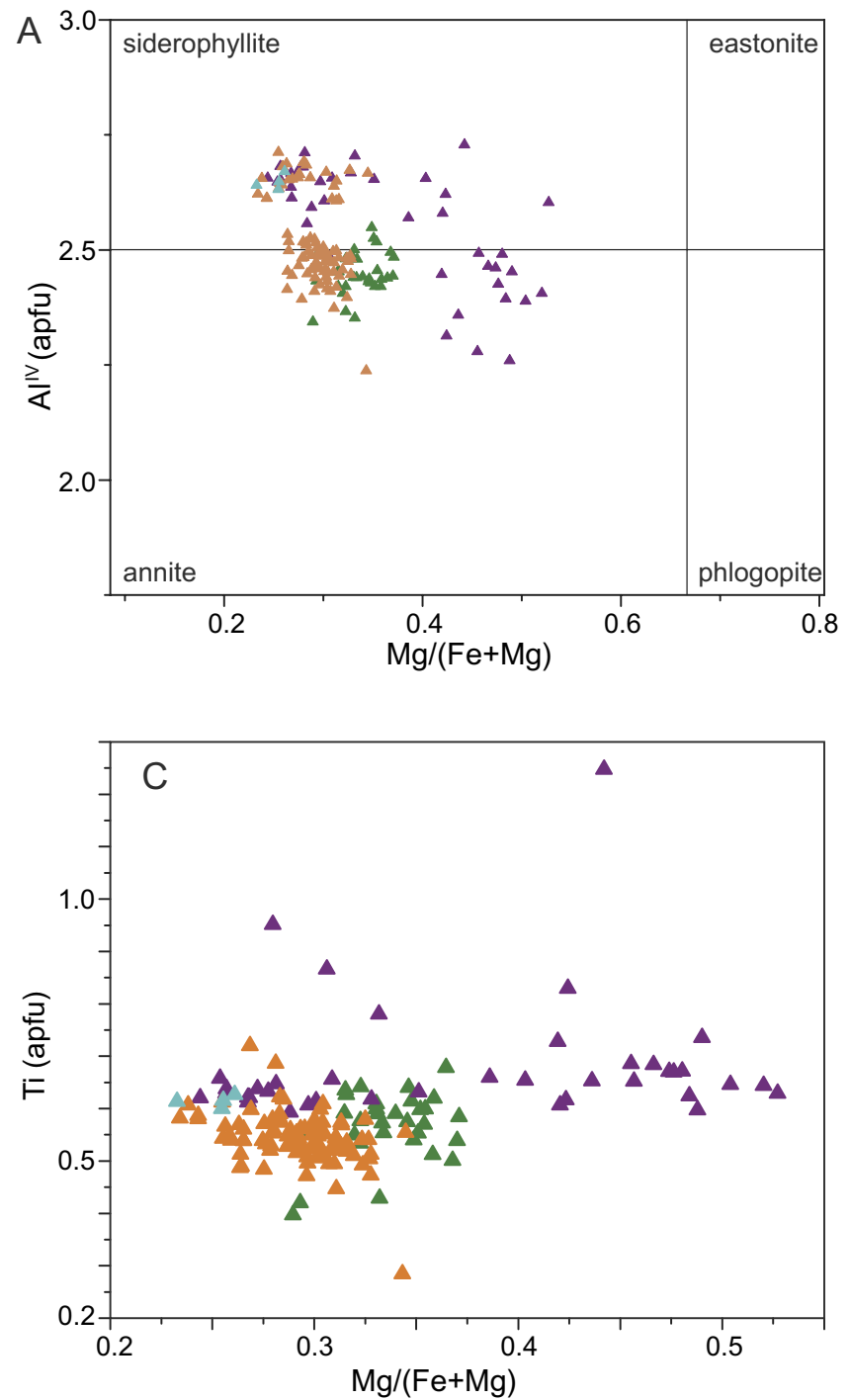

Fig. 13 Mineral chemistry of RVS biotite; selected data from Repstock et al. (2021) included (for symbols see Fig. 9), A) classification plot; B) Mn vs. Mg-number data with no Mn content not plotted; C) $\mathrm{Ti}$ vs. $\mathrm{Mg}$-number; D) $\mathrm{TiO}_{2}-\mathrm{MgO}-\mathrm{FeO} *$ diagram (Nachit et al.

degree of plagioclase fractionation with a higher oxidation state for these post-climactic ignimbrites of the Oschatz Formation (Online Resource Fig. 4, Green 1995). The higher degrees of crustal contamination, indicated by a $\mathrm{La} / \mathrm{Nb}$ ratio of 2.0-2.6 for the Dornreichenbach Ignimbrite and of 2.0-2.3 for the Frohburg Ignimbrite, significant negative $\mathrm{Nb}$ and $\mathrm{Ta}$ anomalies and low $\mathrm{Ti}$ values support this interpretation (Thompson et al. 1984; Cook et al. 2016a, b).

In the Borna Subbasin, the Buchheim Volcanics display REE pattern different from the neighboring Frohburg Ignimbrite suggesting origin from two separate magma batches. A less pronounced negative Eu anomaly of the Buchheim Volcanics implies a less differentiated
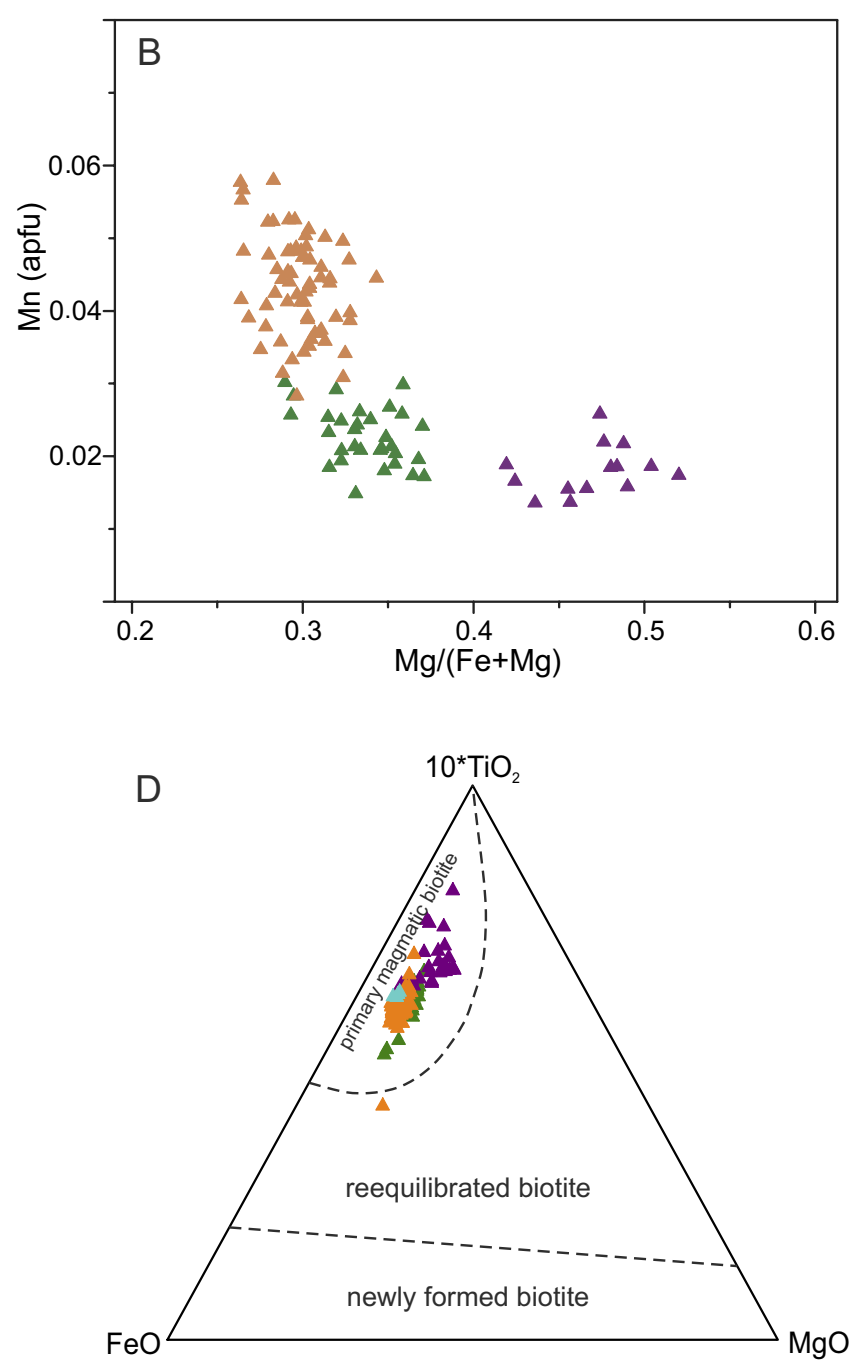

2005). Data from Rochlitz-N are from subtype Thalheim. Biotite of Rochlitz- $\beta$ has higher Ti and Mg contents than other Rochlitz Ignimbrites

magma. Furthermore, based on $\mathrm{Nb} / \mathrm{Ta}$ ratio of $14.7-15.8$ this magma also experienced a lower degree of crustal contamination.

The trachydacitic composition of Rochlitz- $\beta$ suggests origin from a less evolved magma compared to Rochlitz- $\alpha$, which is also supported by the presence of Mg-rich biotite. The Mg-poor and Fe-rich biotite of Rochlitz- $\alpha$ reflects a more differentiated magma. The large range of $X \mathrm{Mg}$ of Rochlitz- $\beta$ biotite suggests presence of different magma zones in the reservoir, resulted from basic intrusions in the crustal magma chamber, tapped by several fissure eruptions. The Mg-rich biotite may represent early cumulates that were extracted after homogenization (Lubbers et al. 2020). In granitic melts, $\mathrm{Mn}$ and $\mathrm{Fe}$ contents increase in biotite with 
Table 2 Evolutionary stages of the RVS

\begin{tabular}{|c|c|c|c|}
\hline Stage & Name & Units & Interpretation \\
\hline S1 pre-caldera & Pre-caldera eruptions & Kohren Formation & $\begin{array}{l}\text { Extrusion of andesitoids at the margin of } \\
\text { the caldera and tuffs } \\
\text { Forming fault structures in the east and } \\
\text { north }\end{array}$ \\
\hline S2 climactic phase 1 & $\begin{array}{l}\text { Caldera forming and eruption of monoto- } \\
\text { nous rhyolites }\end{array}$ & Rochlitz- $\alpha$ Ignimbrite & $\begin{array}{l}\text { Reheating of the non-eruptible crystal-rich, } \\
\text { rhyolitic magma by basic underplating } \\
\text { Homogenization and eruption of volumi- } \\
\text { nous monotonous rhyolites }\end{array}$ \\
\hline S2 climactic phase 2 & $\begin{array}{l}\text { Homogenization due to magma mixing } \\
\text { and eruption of monotonous intermedi- } \\
\text { ates }\end{array}$ & Rochlitz- $\beta$ Ignimbrite & $\begin{array}{l}\text { Ongoing reheating with basic injections } \\
\text { into magma chamber } \\
\text { Magma mixing but incomplete homogeni- } \\
\text { zation } \\
\text { Eruption of monotonous intermediates in } \\
\text { the northwest central area of the RVS }\end{array}$ \\
\hline S3 post-climactic phase 1 & Resurgence & $\begin{array}{l}\text { Leisnig Laccolith } \\
\text { Grimma Laccolith } \\
\text { Kemmlitz Lava }\end{array}$ & $\begin{array}{l}\text { Differentiation of the magma reservoir } \\
\text { Intrusion of Leisnig Laccolith and Grimma } \\
\text { Laccolith leading to a resurgence } \\
\text { Eruption of Kemmlitz Lava in the Mügeln } \\
\text { Subbasin }\end{array}$ \\
\hline S3 post-climactic phase 2 & $\begin{array}{l}\text { Post-climactic eruptions and resting } \\
\text { phase }\end{array}$ & $\begin{array}{l}\text { Dornreichenbach Ignimbrite } \\
\text { Frohburg Ignimbrite } \\
\text { Buchheim Volcanics } \\
\text { Sediments of the Oschatz } \\
\text { Formation }\end{array}$ & $\begin{array}{l}\text { Volcanic activity in Borna and Meltewitz } \\
\text { Subbasin, e.g., eruption of ignimbrites } \\
\text { Small eruptions with deposition of tuffs in } \\
\text { the Mügeln Subbasin } \\
\text { Deposition of sediments } \\
\text { Resting phase before the WVS activity }\end{array}$ \\
\hline
\end{tabular}
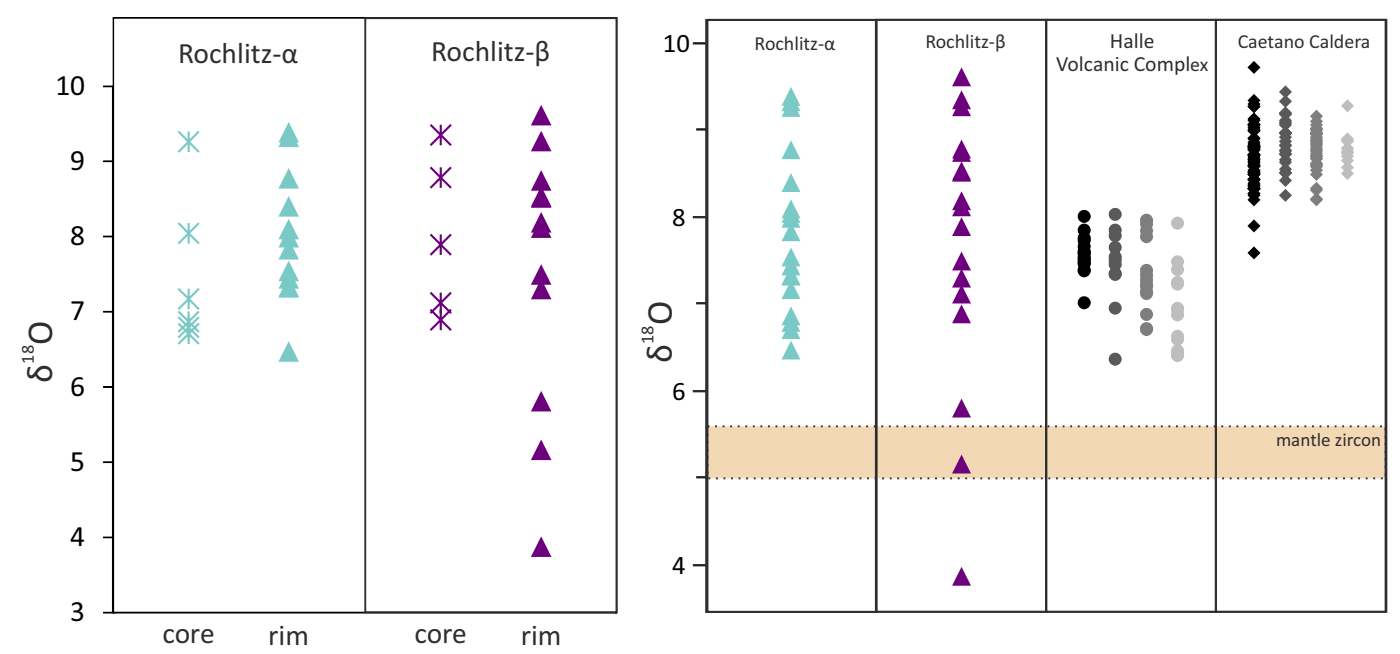

NSVC

*,A Rochlitz- $\alpha$ (core, rim)

*,A Rochlitz- $\beta$ (core, rim)

Halle Volcanic Complex

- Spitzberg

- Wettin

Halle 1390

Halle 1044

Caetano Caldera

- Caetano Tuff, lower unit

- Carico Lake pluton

- Redrock Canyon porphyry

Center caldera lava/plug
Fig. 14 A Zircon $\delta^{18} \mathrm{O}$ of Rochlitz- $\alpha$ and $-\beta$, for values see Online Resource Table 8. B Comparison of zircon $\delta^{18} \mathrm{O}$ from different monotonous rhyolites with the RVS. Data of Halle Volcanic Complex

higher differentiation (Miller and Stoddard 1981). Furthermore, the high values of Mn (0.03-0.06 apfu, 0.2-0.4 wt\%) in Rochlitz- $\alpha$ biotite (compared to Rochlitz- $\beta, 0.01-0.02$ apfu, $0.0-0.1 \mathrm{wt} \%$; Fig. 13B), the more pronounced negative Eu-anomaly (Fig. 11) and the high silica content (Fig. 10) of Rochlitz- $\alpha$ Ignimbrite indicate a higher differentiation. are from Słodczyk et al. (2016) and for Caetano Caldera from Watts et al. (2016). Orange area marks area for zircon formed in the mantle (Valley 2003)

The RVS magma evolution, displaying a trend from voluminous rhyolitic ignimbrites to monotonous intermediates, can be compared with other magmatic centers like the Halle Volcanic Complex (Breitkreuz et al. 2015; Słodczyk et al. 2015, 2016), the Ongatiti Ignimbrite in New Zealand 


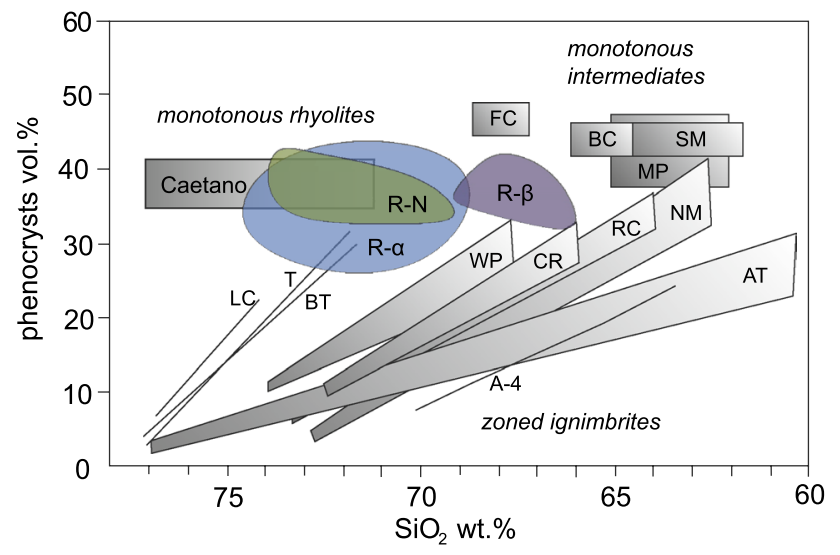

Fig. 15 Phenocryst content vs. $\mathrm{SiO}_{2}$ of Rochlitz Ignimbrites: R- $\alpha-$ Rochlitz- $\alpha$ Ignimbrite, R- $\beta$-Rochlitz- $\beta$ ignimbrite, R-N-Rochlitz-N ignimbrite. Grey bars and lines display composition of ignimbrites from the western USA (data from Hildreth 1981; Lipmann 2000, 2006) and the Caetano Caldera (Watts et al. 2016). For comparison FC-Fish Canyon Tuff; FCM-Fish Creek Mountains Tuff; KNKneeling Nun Tuff; MT-Monotony Tuff; SM-Snowshoe Mountain Tuff; AS-Apache Spring Tuff; AT-Ammonia Tanks; A-4-Aso-4; BT-Bishop Tuff; LC_-Lava Creek Tuff; RM-Ranier Mesa; Scaldera forming eruption of Shikotsu; T-Tshirege; TC-Tiva Canyon; TS-Topopah Spring

(Cooper and Wilson 2014) and the Caetano Caldera (Watts et al. 2016) in the Nevada Great Basin.

The Halle Volcanic Complex (HVC), located northwest of the RVS, is dominated by large laccolith units (Fig. 1). According to Słodczyk et al. (2015) the chemical composition is similar to RVS. The range of $\delta^{18} \mathrm{O}$ in zircon is very limited compared to the variation in RVS (Fig. 14). Thus, the HVC can be considered as a "non-erupted monotonous rhyolite". The synchronous development (300-290 Ma, Breitkreuz et al. 2009; Hoffmann et al. 2013) in an intracontinental extensional setting (Romer et al. 2001), and similar geochemical composition suggest a cogenetic evolution of the RVS and the HVC.

The Ongatiti Ignimbrite and the Caetano Caldera display similarities in the magmatic evolution, whereas the geological setting differs from the tectonic environment of RVS. Both are classified as monotonous rhyolites (Cooper and Wilson 2014; Watts et al. 2016). Watts et al. (2016) postulated an evolution of monotonous rhyolites to monotonous intermediates due to basic injections leading to an eruptible mush for the rhyolitic, crystal-rich magma. Biotite in the Caetano Tuffs shows similar trends in $\mathrm{Mg}$ and Ti enrichment in the upper units like Rochlitz- $\beta$. The initial phase of both systems is characterized by extrusion of andesite melts. Injection of low- $\mathrm{SiO}_{2}$ magma into a $\mathrm{SiO}_{2}$-rich magma chamber induced magma mixing and the formation of a homogenous high- $\mathrm{SiO}_{2}$ cap and a heterogeneous less evolved lower part. After the eruption of the high-volume, crystal-rich Caetano Tuff, a less siliceous magma erupted. The Lower
Caetano Tuff of the Caetano Caldera displays a narrow $\delta^{18} \mathrm{O}$ range in zircon (7.59-9.72\%o, Watts et al. 2016; Fig. 14) like Rochlitz- $\alpha$ leading to interpretation as monotonous rhyolite. Resorption structures in plagioclase of the Upper Caetano Tuff evidence for injections of basic magma and mixing processes forming monotonous intermediates like Rochlitz- $\beta$.

With a calculated melt temperature of $755^{\circ} \mathrm{C}$, a crystal content of approx. $30 \%$ and a volume of more than 1000 $\mathrm{km}^{3}$, the evolution of the RVS is comparable to the eruption conditions of the Ongatiti Ignimbrite of the Taupo Volcanic Zone, New Zealand (more than $500 \mathrm{~km}^{3}$, temperature between 770 and $820^{\circ} \mathrm{C}, 20-30$ vol\% crystal content, Cooper and Wilson 2014). These authors postulated a depth of 4-6 km for the Ongatiti magma reservoir, which is comparable to the calculated minimum depth of $8 \mathrm{~km}$ and a mean depth of $15 \mathrm{~km}$ estimated for RVS.

\section{Conclusions}

Petrographic features, whole-rock analyses, mineral chemistry of biotite and oxygen isotopes in zircon allow to characterize the different ignimbrites and other (sub)volcanic rocks of the RVS. The Rochlitz- $\alpha$ Ignimbrite can be classified as a high-voluminous monotonous rhyolite. In contrast, the following low-volume Rochlitz- $\beta$ Ignimbrite has a trachydacitic composition. High $\mathrm{TiO}_{2}$ and $\mathrm{Zr}$ content in whole-rock and lower $\delta^{18} \mathrm{O}$ in zircon reflect origin from a monotonous intermediate magma which experienced magma mixing by basic injections into a crustal magma chamber.

The evolution of the RVS can be summarized as follows:

1. The minimum volume of RVS can be estimated at 1056 $\mathrm{km}^{3}$ suggesting a magnitude of VEI 8 . The caldera extension $\left(880 \mathrm{~km}^{2}\right)$ is comparable to other large calderas with VEI 8, thus, the RVS represents one of the biggest eruptions in central Europe.

2. The RVS comprises large-volume monotonous rhyolites as well as monotonous intermediates erupted in phase 1 of the climactic stage. Reheating by underplating and injections of basic magma led to the eruption of the crystal-rich melts.

3. During the second phase of the climactic stage, basic injections into a crustal magma chamber caused magma mixing forming a monotonous intermediate composition prior to the eruption of Rochlitz- $\beta$ Ignimbrite.

4. Magma mixing was incomplete as reflected by the wide range of oxygen isotope ratios in zircon of Rochlitz- $\beta$.

5. We consider central fissure eruptions along NW-SEtrending faults as the main eruption style of the RVS resembling characteristics of a piecemeal caldera. Pres- 
Fig. 16 Evolution model of the RVS with stages S1-S3. Stage

1) Pre-caldera eruptions during Kohren Fm.; Stage 2 phase1)

Climactic phase of the Rochlitz caldera with deposition of voluminous, welded rhyolitic Rochlitz- $\alpha$ ignimbrites; Stage 2 phase 2) Termination of the climactic phase with deposition of Ti- and Zr-rich, rhyolitic to trachydacitic welded ignimbrites of Rochlitz- $\beta$ and -N; Stage 3 phase 1) Early post-climactic resurgence phase; emplacement of the Leisnig Laccolith caused resurgence of the Rochlitz caldera and formation of the intracaldera subbasins; emplacement of the Grimma Laccolith in the apex of the resurgent dome; extrusion of the rhyolitic, porphyritic Kemmlitz Lava in the Mügeln Subbasin; Stage 3 phase 2) Late post-climactic phase: eruption of low-volume, strongly welded ignimbrites (Buchheim Volcanics) in the Borna Subbasin; deposition of sediments (e.g., Saalhausen beds, Fig. 6) and low-volume pyroclastic deposits (e.g., Dornreichenbach Ignimbrite); display of the caldera complex is vertically exaggerated
(S1) pre-caldera eruptions (Kohren Fm.) WSW

ENE

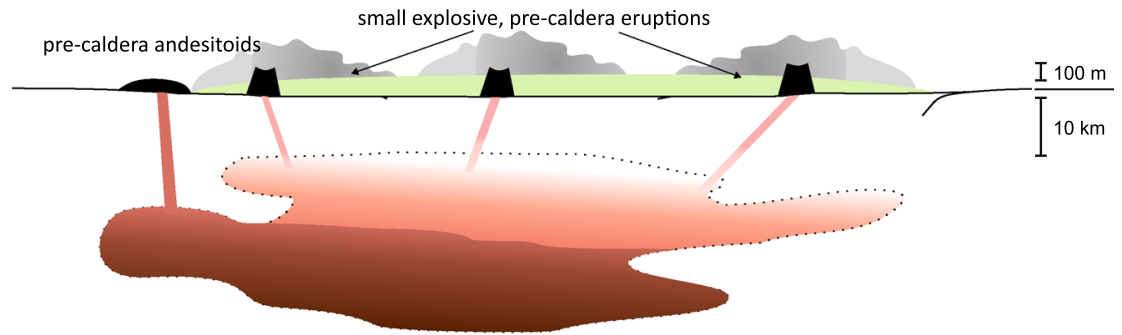

S2 phase 1: climactic caldera forming phase, eruption of monotonous rhyolites (Rochlitz Fm.) WSW

ENE

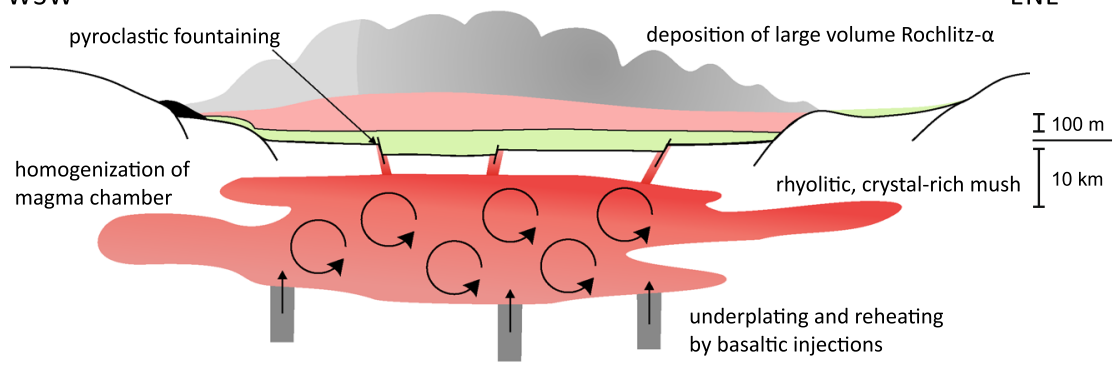

S2 phase 2: climactic homogenization phase, eruption of monotonous intermediates (Rochlitz Fm.) WSW ENE

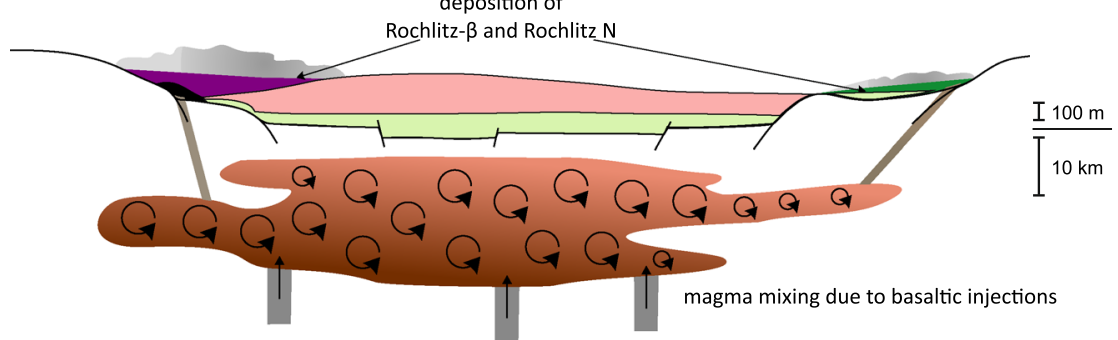

(S3) phase 1: post-climactic resurgence phase, forming of margin subbasins (Rochlitz and Oschatz Fm.)
WSW Borna Subbasin
Mügeln Subbasin
ENE
me subvolcanic Grimma Laccolith

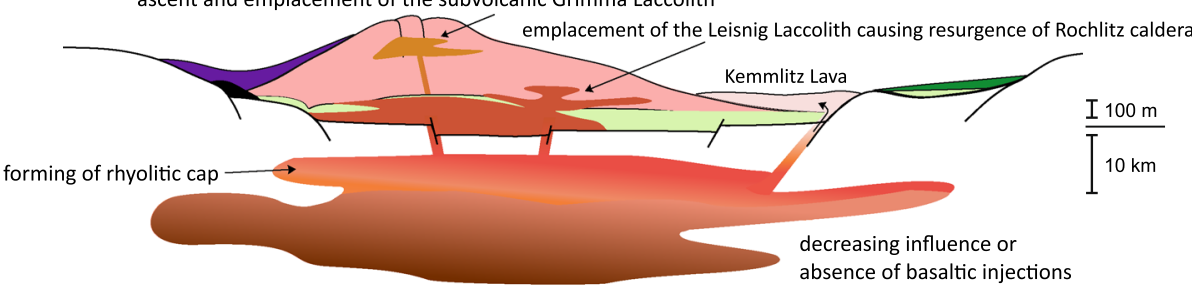

S3 phase 2: post-climactic resurgence phase (Oschatz $\mathrm{Fm}$.)

WSW local eruptions in Borna Subbasin

ENE

(Buchheim Volcanics, Frohburg Ignimbrite) deposition of Oschatz sediments (coal, conglomerates, sands, tuffs)

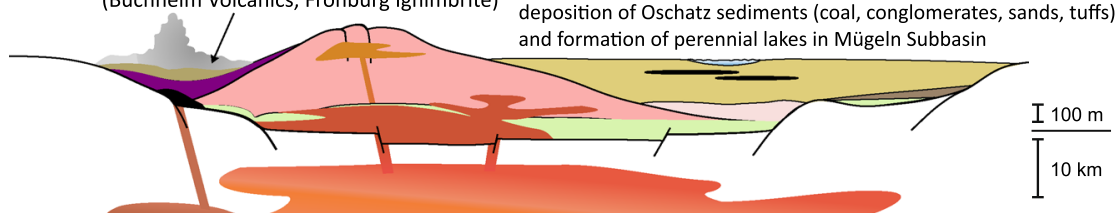


ence of additional vents is displayed by dyke and laccolith complexes at the caldera margin.

6. The rhyolitic subvolcanic units in the caldera center can be confirmed as laccolith complexes, emplaced below and into Rochlitz Ignimbrites, respectively, during the post-climactic stage. Their intrusion led to a caldera resurgence forming three subbasins in the periphery.

7. The subdivision of the Rochlitz Ignimbrites into four subunits $\left(\mathrm{R}_{\mathrm{I}-\mathrm{III}}\right.$ and $\left.\mathrm{R}_{\mathrm{N}}\right)$, as proposed in previous studies, cannot be maintained. Instead, based on geochemical composition, a new subdivision is postulated. Rochlitz- $\alpha$ and $-\beta$ Ignimbrites dominate. Besides, Rochlitz-N Ignimbrites locally occur can be further classified as Schöna type in the North and Thalheim type in the East.

8. An increasing differentiation in the magma chamber after the eruption of the monotonous intermediates is shown by the numerous low-volume ignimbrites erupted in the second phase of the post-climactic stage.

9. A correlation of the post-climactic succession (Oschatz Formation) in the three subbasins is not possible due to their different lithostratigraphy; however, a general cogenetic evolution in post-caldera depressions can be assumed.

Supplementary Information The online version contains supplementary material available at https://doi.org/10.1007/s00531-021-02053-5.

\begin{abstract}
Acknowledgements Frank Eigenfeld generously allocated data and 208 additional thin sections related to his Ph.D. project. The research was supported by the Saxon State Office for Environment, Agriculture and Geology, Department of Geology and by the Geology Department of the Technical University of Freiberg. Thanks go to the Saxon State Office for Environment, Agriculture and Geology and to the Wismut $\mathrm{GmbH}$ for allowing access to drilling documentation and cores. Results from master theses of Axel Rommel and Jan Rehda (2017, 2018, respectively, both TU Bergakademie Freiberg) have been incorporated in this study. We thank Lutz Hecht and Peter Czaja for EPMA analyses as well as Kirsten Born, all Leibnitz Museum für Naturkunde Berlin, for SEM measurements. We are very grateful for the careful reviews by Sergio Rocchi and Karsten Obst.
\end{abstract}

Funding Open Access funding enabled and organized by Projekt DEAL. The research was supported by the Saxon State Office for Environment, Agriculture and Geology, Department of Geology and by the Geology Department of the Technical University of Freiberg.

Availability of data and materials Data used in the manuscript are available by sending an email to the corresponding author and in the electronic supplement.

Open Access This article is licensed under a Creative Commons Attribution 4.0 International License, which permits use, sharing, adaptation, distribution and reproduction in any medium or format, as long as you give appropriate credit to the original author(s) and the source, provide a link to the Creative Commons licence, and indicate if changes were made. The images or other third party material in this article are included in the article's Creative Commons licence, unless indicated otherwise in a credit line to the material. If material is not included in the article's Creative Commons licence and your intended use is not permitted by statutory regulation or exceeds the permitted use, you will need to obtain permission directly from the copyright holder. To view a copy of this licence, visit http://creativecommons.org/licenses/by/4.0/.

\section{References}

Anegg R (1970) Zur Petrographie und Vulkanotektonik des Grimmaer Quarzporphyrs im Nordsächsischen Vulkanitkomplex. Wissenschaftliche Zeitschrift, Universität Halle 4:79-86

Awdankiewicz M (1999) Volcanism in a late Variscan intramontane trough - the petrology and geochemistry of the Carboniferous and Permian volcanic rocks of the intra-sudetic basin. Geol Sudet 32:83-111

Awdankiewicz M, Breitkreuz C, Ehling, B-C (2004) Emplacement textures in Late Palaeozoic andesite sills of the FlechtingenRoßlau Block, north of Magdeburg (Germany). In: Breitkreuz, C, Petford N (eds) Physical geology of high-level magmatic systems. Geological Society, London, Special Publication, vol 234, pp 51-66

Bachmann O, Bergantz GW (2004) On the origin of crystal-poor rhyolites. Extracted from batholithic crystal mushes. J Petrol 45(8):1565-1582. https://doi.org/10.1093/petrology/egh019

Bachmann O, Bergantz GW (2008a) Deciphering magma chamber dynamics from styles of compositional zoning in large silicic ash flow sheets. In: Putirka KD Tepley FJ (eds) Minerals, inclusions and volcanic processes. Mineralogical Society of America and Geochemical Society, Reviews in Mineralogy and Geochemistry, vol 69, pp 651-674

Bachmann O, Bergantz GW (2008) The Magma reservoirs that feed supereruptions. Elements 4(1):17-21. https://doi.org/10.2113/ GSELEMENTS.4.1.17

Bachmann O, Huber C (2016) Silicic magma reservoirs in the Earth's crust. Am Miner 101(11):2377-2404. https://doi.org/10.2138/ am-2016-5675

Bachmann O, Dungan MA, Lipman PW (2000) Voluminous lava-like precursor to a major ash-flow tuff. Low-column pyroclastic eruption of the Pagosa Peak Dacite, San Juan volcanic field Colorado. J Volcanol Geotherm Res 98(1-4):153-171. https:// doi.org/10.1016/S0377-0273(99)00185-7

Bachmann O, Dungan MA, Lipman PW (2002) The Fish Canyon Magma Body, San Juan Volcanic Field, Colorado Rejuvenation and Eruption of an Upper-Crustal Batholith. J Petrol 43(8):1469-1504

Ballouard C, Poujol M, Boulvais P, Branquet Y, Tartèse R, Vigneresse JL (2015) Is the Nb-Ta fractionation a marker of an interaction with fluids in peraluminous granites? SGA2015: 13th biennial meeting. Nancy, France

Barthel M, Götzelt V, Urban G (1976) Die Rotliegendflora Sachsens. Abhandlungen des Staatlichen Museums für Mineralogie und Geologie, Dresden, vol 24

Benek R (1980) Geologisch-strukturelle Untersuchungen im Tharandter Vulkanitkomplex (Südteil DDR). Z Geol Wiss 8:627-643

Benek R, Jentsch F, Pälchen W, Röllig G (1977) Die permosilesichen Vulkanite von Meißen, des Tharandter Waldes und des Osterzgebirges. Variszischer subsequenter Vulkanismus. Exkursionsführer Tagung Ges Geol Wiss DDR, Leipzig, pp 52-69

Benek R, Kramer W, McCann T, Scheck M, Negendank JFW, Korich D (1996) Permo-Carboniferous magmatism of the Northeast German Basin. Tectonophysics 266(1-4):379-404. https://doi.org/ 10.1016/S0040-1951(96)00199-0 
Boy JA, Haneke J, Kowalczyk G, Lorenz V, Schindler T, Stollhofen H, Thum H (2012) Rotliegend im Saar-Nahe-Becken, am Taunus-Südrand und im nördlichen Oberrheingraben. In: Lützner H, Kowalczyk G (eds.): Stratigraphie von Deutschland X. Rotliegend. Teil I: Innervariszische Becken. Schriftenreihe der deutschen Gesellschaft für Geowissenschaften, vol 61, Hannover, pp 254-377

Branney MJ, Kokelaar P (1994) Volcanotectonic faulting, soft-state deformation, and rheomorphism of tuffs during development of a piecemeal caldera, English Lake District. Geol Soc Am Bull 106(4):507-530

Branney MJ, Kokelaar P (2002) Pyroclastic density currents and the sedimentation of ignimbrites. Geological Society of London

Branney MJ, Bonnichsen B, Andrews GDM, Ellis B, Barry TL, McCurry M (2008) 'Snake River (SR) -type' volcanism at the Yellowstone hotspot track: distinctive products from unusual, high-temperature silicic super-eruptions. Bull Volcanol 70:293314. https://doi.org/10.1007/s00445-007-0140-7

Breiter K, Novák JK, Chlupáčová M (2001) Chemical evolution of volcanic rocks in the Altenberg-Teplice caldera (Eastern Krušné Hory Mts., Czech Republic, Germany). Geolines 13:17-22

Breiter K, Svojtka M, Ackerman L, Švecová K (2012) Trace element composition of quartz from the Variscan Altenberg-Teplice caldera (Krušné hory/Erzgebirge Mts, Czech Republic/Germany): insights into the volcano-plutonic complex evolution. Chem Geol 326:36-50

Breitkreuz C, Kennedy A, Geißler M, Ehling B-C, Kopp J, Muszynski A, Protas A, Stouge S (2007) Far Eastern Avalonia. Its chronostratigraphic structure revealed by SHRIMP zircon ages from Upper Carboniferous to Lower Permian volcanic rocks (drill cores from Germany, Poland, and Denmark). In: Linnemann U (ed) The evolution of the Rheic Ocean. From Avalonian-Cadomian active margin to Alleghenian-Variscan collision, Bd. 423. Boulder, Colo: Geological Soc. of America (Special paper/Geological Society of America, vol 423, pp 173-190

Breitkreuz C, Ehling B-C, Sergeev S (2009) Chronological evolution of an intrusive/extrusive system: the Late Paleozoic Halle Volcanic Complex in the northeastern Saale Basin (Germany). Z dt Ges Geowiss 160:173-190

Breitkreuz C, Ehling, B-C, Pastrik N (2015) The subvolcanic units of the Late Paleozoic Halle Volcanic Complex, Germany: geometry, internal textures and emplacement mode. In: Breitkreuz C, Rocchi S (eds) Physical geology of shallow magmatic systems. Advances in volcanology, Springer, Cambridge, pp 295-307

Breitkreuz C, Ehling B-C, Pastrik N (2018) The subvolcanic units of the Late Palaeozoic Halle Volcanic Complex, Germany: Geometry, internal textures and emplacement mode. In: Breitkreuz C, Rocchi S (eds) Physical geology of shallow magmatic systemsdykes, sills and laccoliths. Advances in volcanology. Springer, pp 295-307

Breitkreuz C, Käßner A, Tichomirowa M, Lapp M, Huang S, Stanek K (2021) The Late Carboniferous deeply eroded Tharandt Forest caldera-Niederbobritzsch granite complex: a post-Variscan long-lived magmatic system in central Europe. Int J Earth Sci 110:1265-1292. https://doi.org/10.1007/s00531-021-02015-x

Casas-García R, Rapprich V, Breitkreuz C, Svojtka M, Lapp M, Stanek K, Hofmann M, Linnemann U (2019) Lithofacies architecture, composition, and age of the Carboniferous Teplice Rhyolite (German-Czech border): insights into the evolution of the Altenberg-Teplice Caldera. J Volc Geoth Res 386:106662

Chamberlain KJ, Wilson CJ, Wooden JL, Charlier BL, Ireland TR (2014) New perspectives on the Bishop Tuff from zircon textures, ages and trace elements. J Petrol 55(2):395-426

Chiaradia M, Müntener O, Beate B, Fontignie D (2009) Adakite-like volcanism of Ecuador: lower crust magmatic evolution and recycling. Contrib Mineral Petrol 158(5):563-588
Christiansen EH (2005) Contrasting processes in silicic magma chambers. Evidence from very large volume ignimbrites. Geol Mag 142(6):669-681. https://doi.org/10.1017/S0016756805001445

Cole JW, Milner DM, Spinks KD (2005) Calderas and caldera structures: a review. Earth Sci Rev 69(1-2):1-26

Cook GW, Wolff JA, Self S (2016) Estimating the eruptive volume of a large pyroclastic body: the Otowi Member of the Bandelier Tuff, Valles caldera, New Mexico. Bull Volcanol 78(2):10. https://doi. org/10.1007/s00445-016-1000-0

Cook YA, Sanislav IV, Hammerli J, Blenkinsop TG, Dirks PHGM (2016) A primitive mantle source for the Neoarchean mafic rocks from the Tanzania Craton. Geosci Front 7(6):911-926. https:// doi.org/10.1016/j.gsf.2015.11.008

Cooper GF, Wilson CJN (2014) Development, mobilisation and eruption of a large crystal-rich rhyolite. The Ongatiti ignimbrite, New Zealand. Lithos 198-199:38-57. https://doi.org/10.1016/j.lithos. 2014.03.014

Dill HG, Dohrmann R, Kaufhold S, Balaban SI (2015) Kaolinizationa tool to unravel the formation and unroofing of the Pleystein pegmatite-aplite system (SE Germany). Ore Geol Rev 69:33-56

Dostal J, Elson C, Dupuy C (1979) Distribution of lead, silver and cadmium in some igneous rocks and their constituent minerals. Can Mineral 17(3):561-567

Ehling B-C, Gebhardt U (2012) Rotliegend im Saale-Becken. In: Lützner H, Kowalczyk G (eds) Stratigraphie von Deutschland X. Rotliegend. Teil I: Innervariszische Becken. Hannover: Schriftenreihe der deutschen Gesellschaft für Geowissenschaften, pp 504-516

Eigenfeld F (1978) Zur geologischen Entwicklung der vulkanischen Gesteine im Süd- und Ostteil des NW-Sächsischen Vulkanitkomplexes. Diss., Fachber. Geol. Wiss., Martin Luther-Univ. HalleWittenberg, Halle (Saale) (unpublished)

Ellis BS, Wolff JA, Boroughs S, Mark DF, Starkel WA, Bonnichsen B (2013) Rhyolitic volcanism of the central Snake River Plain: a review. Bull Volcanol 75(8):745

Fischer I (1968) Geologische Untersuchungen am Kernmaterial der Bohrung Meltewitz 1/66 (Sa.) diploma thesis, Martin-LutherUniversity, Halle-Wittenberg (unpublished)

Fischer F (1991) Das Rotliegende des ostthüringisch-westsächsischen Raumes (Vorerzgebirgs-Senke, Nordwestsächsischer Vulkanitkomplex, Geraer Becken). Diss., Sektion Geowiss., TU Bergakademie Freiberg, Freiberg (unpublished)

Folkes C, Wright H, Cas R, De Silva S, Lesti C, Viramonte J (2011) A re-appraisal of the stratigraphy and volcanology of the Cerro Galan volcanic system, NW Argentina. Bull Volcanol 73(10):1427-1454. https://doi.org/10.1007/s00445-011-0459-y

Fridrich CJ, Smith RP, Dewitt ED, Mckee EH (1991) Structural, eruptive, and intrusive evolution of the Grizzly Peak caldera, Sawatch Range, Colorado. Geol Soc Am Bull 103(9):1160-1177. https:// doi.org/10.1130/0016-7606(1991)103\%3c1160:SEAIEO\%3e2.3. $\mathrm{CO} ; 2$

Geißler M, Breitkreuz C, Kiersnowski H (2008) Late Palaeozoic volcanism in the central part of the Southern Permian Basin (NE Germany, W Poland). Facies distribution and volcano-topographic hiati. Int J Earth Sci 97(5):973-989

Gifkins C, Herrmann W, Large RR (2005) Altered volcanic rocks. A guide to description and interpretation, Hobart, Tasmania. Centre for Ore Deposit Research

Gläßer W (1983) Beitrag zur Petrologie und Vulkanologie der andesitoiden Vulkanite Nordwestsachsens. Hallesches Jb F Geowiss $8: 1-30$

Götze J, Lessig F, Möckel R, Georgi U (2017) Zur Mineralogie von Vulkaniten im Bereich des Kemmlitzer Porphyrs (OschatzFormation, Nordwestsächsisches Becken). Veröff Mus Naturk Chemnitz 40:133-150 
Götze J, Möckel R, Breitkreuz C, Georgi U, Klein A (2020) Zur Mineralogie von Vulkaniten und Lithophysen im Bereich des unterpermischen Leisniger Porphyrs (Nordwestsächsisches Becken). Veröff Mus Naturk Chemnitz 43:79-112

Green TH (1995) Significance of Nb/Ta as an indicator of geochemical processes in the crust-mantle system. Chem Geol 120:347-359

Henry CD, John DA (2013) Magmatism, ash-flow tuffs, and calderas of the ignimbrite flareup in the western Nevada volcanic field, Great Basin, USA. Geosphere 9(4):951-1008. https://doi.org/10. 1130/GES00867.1

Henry DJ, Guidotti CV, Thomson A (2005) The Ti-saturation surface for low-to-medium pressure metapelitic biotites Implications for geothermometry and Ti-substitution mechanisms. Am Mineral 90(2-3):316-328. https://doi.org/10.2138/am.2005.1498

Hildreth W (1981) Gradients in silicic magma chambers. Implications for lithospheric magmatism. J Geophys Res 86(B11):1015310192. https://doi.org/10.1029/JB086iB11p10153

Hildreth W (2004) Volcanological perspectives on Long Valley, Mammoth Mountain, and Mono Craters. Several contiguous but discrete systems. J Volcanol Geotherm Res 136(3-4):169-198. https://doi.org/10.1016/j.jvolgeores.2004.05.019

Hildreth W, Mahood GA (1986) Ring-fracture eruption of the Bishop Tuff. Geol Soc Am Bull 97:396-403

Hoffmann U, Breitkreuz C, Breiter K, Sergeev S, Stanek K, Tichomirowa M (2013) Carboniferous-Permian volcanic evolution in Central Europe- $-\mathrm{U} / \mathrm{Pb}$ ages of volcanic rocks in Saxony (Germany) and northern Bohemia (Czech Republic). Int J Earth Sci 102(1):73-99. https://doi.org/10.1007/s00531-012-0791-2

Hohl R, Wilsdorf E (1966) Der Leisniger Quarzporphyr des nordsächsischen Porphyrgebietes und seine Verwitterung. N. Jb. Geol. Paläont. Mh., 4-13.

Horsman E, Morgan S, de Saint-Blanquat M, Habert G, Nugent A, Hunter RA, Tikoff B (2009) Emplacement and assembly of shallow intrusions from multiple magma pulses, Henry Mountains, Utah. Earth Environ Sci Trans R Soc Edinb 100(1-2):117-132

Huber C, Bachmann O, Manga M (2009) Homogenization processes in silicic magma chambers by stirring and mushification (latent heat buffering). Earth Planet Sci Lett 283(1-4):38-47. https:// doi.org/10.1016/j.eps1.2009.03.029

Huber C, Bachmann O, Dufek J (2012) Crystal-poor versus crystalrich ignimbrites: a competition between stirring and reactivation. Geol 40:115-118

Hutton DHW (2009) Insights into magmatism in volcanic margins: bridge structures and a new mechanism of basic sill emplacement-Theron Mountains, Antarctica. Pet Geosci 15(3):269-278

Ickert RB, Hiess J, Williams IS, Holden P, Ireland TR, Lanc P, Schramm N, Foster JJ, Clement SW (2008) Determining high precision, in situ, oxygen isotope ratios with a SHRIMP II: Analyses of MPI-DING silicate-glass reference materials and zircon from contrasting granites. Chem Geol 257(1-2):114-128

Ishikawa Y, Sawaguchi T, Iwaya S, Horiuchi M (1976) Delineation of prospecting targets for kuroko deposits based on modes of volcanism of underlying dacite and alteration Halos. Min Geol 26:105-117

Jentsch F (1979) Zur minerogenetischen Bedeutung der Gesteinsgläser des Magmatismus des Subsequenzstadiums im sächsischen Raum. - Diss., TU Bergakademie Freiberg, Freiberg. (unpublished)

John DA, Colgan JP, Henry CD, Wooden JL (2009) Prolonged Eocene magmatism culminating with the Caetano caldera, Cortez area, Nevada: Inferences from SHRIMP U-Pb zircon dating: Eos (Transactions, American Geophysical Union), 90 (52), Fall Meeting Supplement, Abstract V41B-2187
Johnston EN, Sparks RSJ, Phillips JC, Carey S (2014) Revised estimates for the volume of the Late Bronze Age Minoan eruption, Santorini, Greece. J Geol Soc 171(4):583-590

Kaiser JF, de Silva S, Schmitt AK, Economos R, Sunagua M (2017) Million-year melt-presence in monotonous intermediate magma for a volcanic-plutonic assemblage in the Central Andes. Contrasting histories of crystal-rich and crystal-poor super-sized silicic magmas. Earth Planet Sci Lett 457:73-86. https://doi.org/ 10.1016/j.epsl.2016.09.048

Kennedy B, Wilcock J, Stix J (2012) Caldera resurgence during magma replenishment and rejuvenation at Valles and Lake City calderas. Bull Volcanol 74(8):1833-1847. https://doi.org/10.1007/ s00445-012-0641-x

Kuhn B (1968) Vulkanotektonische und petrographische Untersuchungen im Rochlitzer Quarzporphyrkomplex Nordwestsachsen (Gebiet Bad Lausick-Großbothen-Colditz). dipl. thesis, MartinLuther-University, Halle-Witternberg (unpublished)

Lubbers J, Deering C, Bachmann O (2020) Genesis of rhyolitic melts in the upper crust: fractionation and remobilization of an intermediate cumulate at Lake City caldera, Colorado, USA. J Volcanol Geoth Res 392:106750

Le Maitre RW, Bateman P, Dudek A, Keller J, Lameyre Le Bas MJ, Sabine PA, Schmid R, Sorensen H, Streckeisen A, Woolley AR, Zanettin B (1989) A classification of igneous rocks and glossary of term. Blackwell, Oxford

Lipman PW (1976) Caldera-collapse breccias in the western San Juan Mountains, Colorado. Geol Soc Am Bull 87(10):1397-1410

Lipman PW (1984) The roots of ash flow calderas in western North America: Windows into the tops of granitic batholiths. J Geophys Res 89(B10):8801-8841. https://doi.org/10.1029/JB089 iB10p08801

Lipman PW (1997) Subsidence of ash-flow calderas: relation to caldera size and magma-chamber geometry. Bull Volcanol 59(3): 198-218

Lipman PW (2000) The central San Juan Caldera cluster: Regional volcanic framework. In: Bethke PM, Hay RL (eds) Ancient Lake Creede: its volcano-tectonic setting, history of sedimentation, and relation of mineralization in the Creede mining district. Geological Society of America Special Paper, vol 346, pp 9-69. https://doi.org/10.1130/0-8137-2346-9.9

Lipman PW (2006) Geologic map of the central San Juan Caldera cluster, southwestern Colorado. U.S. Geological Survey Geologic Investigations Series I-2799, 4 sheets, scale 1:24,000

Lorenz V, Haneke J (2004) Relationship between diatreme, dykes, sills, laccoliths, intrusive-extrusive domes, lava flows and tephra deposits with unconsolidated water-saturated sediments in the late Variscan intermontane Saar-Nahe Basin, SW Germany. In: Breitkreutz C, Petford N (eds) Physical geology of high-level magmatic systems. Geological Society of London, Special Publications, vol 234, pp 75-124, London

Manley CR (1996) In situ formation of welded tuff-like textures in the carapace of a voluminous silicic lava flow, Owyhee County, SW Idaho. Bull Volcanol 57:672-686

Manley CR, Fink JH (1987) Internal textures of rhyolite flows as revealed by research drilling. Geology 15(6):549-552

Mason BG, Pyle DM, Oppenheimer C (2004) The size and frequency of the largest explosive eruptions on Earth. Bull Volcanol 66(8):735-748

Matthews NE, Pyle DM, Smith VC, Wilson CJN, Huber C, van Hinsberg V (2012) Quartz zoning and the pre-eruptive evolution of the $~ 340-\mathrm{ka}$ Whakamaru magma systems, New Zealand. Contr Miner Petrol 163(1):87-107. https://doi.org/10.1007/ s00410-011-0660-1 
McDonough WF, Sun S-S (1995) The composition of Earth. Chem Geol 120:223-253

Miller CF, Stoddard EF (1981) The role of manganese in the paragenesis of magmatic garnet. An example from the Old Woman-Piute Range, California. J Geol 89(2):233-246. https://doi.org/10. $1086 / 628582$

Mlčoch B, Skácelová Z (2010) Geometry of the Altenberg-Teplice Caldera revealed by the borehole and seismic data in its Czech part. J Geosci 55(3):217-229

Nachit H, Ibhi A, Ohoud MB (2005) Discrimination between primary magmatic biotites, reequilibrated biotites and neoformed biotites. CR Geosci 337(16): 1415-1420

Newhall CG, Self S (1982) The volcanic explosivity index (VEI) an estimate of explosive magnitude for historical volcanism. J Geophys Res 87(C2):1231-1238. https://doi.org/10.1029/JC087 iC02p01231

Patiño Douce AE, Johnston AD (1991) Phase equilibria and melt productivity in the pelitic system: implications for the origin of peraluminous granitoids and aluminous granulites. Contrib Mineral Petrol 107:202-218

Paulick H, Breitkreuz C (2005) The Late Palaeozoic felsic lava-dominated large igneous province in northeast Germany. Volcanic facies analysis based on drill cores. Int J Earth Sci 94(5-6):834850. https://doi.org/10.1007/s00531-005-0017-y

Pearce JA (1996) A user's guide to basalt discrimination diagrams. In: Wyman DA (ed) Trace element geochemistry of volcanic rocks: applications for massive sulphide exploration. Geological Association of Canada, Short Course Notes, vol 12, pp 79-113

Pietzsch K (1962) Geologie von Sachsen, 1st edn. VEB Dtsch. Verl. Wiss, Berlin

Quane SL, Russell JK (2005) Ranking welding intensity in pyroclastic deposits. Bull Volcanol 67(2):129-143

Rampino MR, Self S (1992) Volcanic winter and accelerated glaciation following the Toba super-eruption. Nature 359:50-52

Reichel W, Schneider JW (2012) Rotliegend im Döhlen-Becken. Deutsche Stratigraphische Kommission. In: Lützner H, Kowalczyk G (eds) Stratigraphie von Deutschland X. Rotliegend. Teil I: Innervariscische Becken. Schriftenreihe der Deutschen Gesellschaft für Geowissenschaften, vol 61, pp 589-625, Hannover

Repstock A, Breitkreuz C, Lapp M, Schulz B (2018) Voluminous and crystal-rich igneous rocks of the Permian Wurzen volcanic system, northern Saxony, Germany. Physical volcanology and geochemical characterization. Int J Earth Sci 6(9):1485-1513. https://doi.org/10.1007/s00531-017-1554-x

Repstock A, Heuer F, Im J, Hübner M, Schulz B, Breitkreuz C, Gilbricht S, Fischer F, Lapp M (2019) A Late Paleozoic Snake River-type ignimbrite (Planitz vitrophyre) in the Chemnitz Basin, Germany: Textural and compositional evidence for complex magma evolution in an intraplate setting. J Volcanol Geoth Res 369:35-49

Repstock A, Breitkreuz C, Schulz B, Heuer F, Gilbricht S, Lapp M, Gevorgyan H (2021) The Early Permian intraplate Wurzen caldera system of northern Saxony, Germany: insights into magma chamber dynamics and implications for the eruption of a crystalrich monotonous intermediate ignimbrite. J Volcanol Geothermal Res (under review)

Rocchi S, Breitkreuz C (2018) Physical Geology of Shallow-level magmatic systems - an Introduction. In: Breitkreuz C, Rocchi S (eds) Physical geology of shallow magmatic systems-dykes, sills and laccoliths. Advances in volcanology. Springer, pp 1-10

Roche O, Druitt TH, Merle O (2000) Experimental study of caldera formation. J Geophys Res 105(B1):395-416. https://doi.org/10. 1029/1999JB900298

Röllig G (1969) Beiträge zur Petrogenese und Vulkanotektonik der Pyroxenquarzporphyre Nordwestsachsens. Diss., Martin LutherUniv. Halle-Wittenberg, Halle (Saale) (unpublished)
Röllig G (1976) Zur Petrogenese und Vulkanotektonik der Pyroxenquarzporphyre (Ignimbrite) des Nordsächsischen Vulkanitkomplexes. Jb. f. Geol., 5/6 f. 1969/70: 175-268, Berlin

Röllig G, Eigenfeld F, Fischer I, Kuhn B (1970) Die Ignimbrite des Nordsächsischen Vulkanitkomplexes. Wiss z Univ Halle 19:67-78

Romer RL, Förster H, Breitkreuz C (2001) Intracontinental extensional magmatism with a subduction fingerprint: the late Carboniferous Halle Volcanic Complex (Germany). Contrib Mineral Petrol 141:201-221

Schneider JW, Rößler R, Fischer F (2012) Rotliegend des ChemnitzBeckens (syn. Erzgebirge-Becken). In: Lützner H, Kowalczyk G (eds) Stratigraphie von Deutschland X. Rotliegend. Teil I: Innervariszische Becken, Schriftenreihe der deutschen Gesellschaft für Geowissenschaften, vol 61, pp 530-588 Hannover

Schwerdtner G, Störr M (1983) Die Kaolinlagerstätten des Gebietes Kemmlitz/Bezirk Leipzig - Genese, Geologie und Stoffbestand, wirtschaftliche Bedeutung. Silikattechnik, vol 34(6), pp 169174, Berlin

Słodczyk E, Pietranik A, Breitkreuz C, Pędziwiatr A, Bokła M, Schab K, Grodzicka M (2015) Formation of a laccolith by magma pulses: Evidence from modal and chemical composition of the $500 \mathrm{~m}$ long borehole section through the Permo-Carboniferous Landsberg laccolith (Halle Volcanic Complex). Geochem J 49(5):523-537

Słodczyk E, Pietranik A, Breitkreuz C, Fanning CM, Anczkiewicz R, Ehling B-C (2016) Rhyolite magma evolution recorded in isotope and trace element composition of zircon from Halle Volcanic Complex. Lithos 248:402-417

Smith RL (1979) Ash-flow magmatism. In: Chapin CE, Elston WE (eds) Ash-flow tuffs, 180, Geological Society of America, Boulder, Colo. (Special paper, 180), pp 5-28

Sun S-S, McDonough WF (1989) Chemical and isotopic systematics of oceanic basalts. Implications for mantle composition and processes. Geological Society, London, Special Publications, vol 42, no 1, pp 313-345. https://doi.org/10.1144/GSL.SP.1989.042. 01.19

Thompson RN, Morrison MA, Hendry GL, Parry SJ (1984) An assessment of the relative roles of crust and mantle in magma genesis. An elemental approach. Philos Trans R Soc Lond Ser A Math Phys Sci 310(1514):549-590. https://doi.org/10.1098/rsta.1984. 0008

Timmerman MJ (2008) Palaeozoic magmatism. In: McCann T (ed) The geology of Central Europe, vol 1. Precambrian and Palaeozoic. Geological Society, London, pp 665-748

Valley JW (2003) Oxygen isotopes in zircon. In: Hanchar JM, Hoskin PWO (eds) Zircon Rev Mineral, vol 53, pp 343--385

Vogel TA, Patino LC, Alvarado GE, Gans PB (2004) Silicic ignimbrites within the Costa Rican volcanic front. Evidence for the formation of continental crust. Earth Planet Sci Lett 226(1-2):149-159. https://doi.org/10.1016/j.epsl.2004.07.013

Walter H (1991) Zum Alter der Kaolinisierung in Sachsen. Mauritiana, vol 13, no 1/2, pp 213-224, Altenburg

Walter H (2006) Das Rotliegende der Nordwestsächsischen Senke. Veröff Mus Naturkunde Chemnitz 29:157-176

Walter H (2010) Die wissenschaftliche Grabung Börtewitz: Lebewelt eines 290 Mio. Jahre alten Sees. In: Rascher J, Heidenfelder W, Walter H (eds) Landschaftsentwicklung, Bodenschätze und Bergbau zwischen Mulde und Elbe (Nordwestsachsen). Exkursionsführer und Veröffentlichung DGG, vol 243. Hannover, pp 51-64

Walter H (2012) Rotliegend im Nordwestsächsischen Becken. In: Lützner H, Kowalczyk G (eds) Stratigraphie von Deutschland X. Rotliegend. Teil I: Innervariszische Becken, Schriftenreihe der deutschen Gesellschaft für Geowissenschaften, vol 61, Hannover, pp 517-529 
Walther D, Breitkreuz C, Rapprich V, Kochergina YV, Chlupáčová M, Lapp M, Stanek K, Magna T (2016) The Late Carboniferous Schönfeld-Altenberg Depression on the NW margin of the Bohemian Massif (Germany/Czech Republic). Volcanosediment Magmat Evol J Geosci 4(61):371-393. https://doi.org/10.3190/ jgeosci.219

Watts KE, John DA, Colgan JP, Henry CD, Bindeman IN, Schmitt AK (2016) Probing the volcanic-plutonic connection and the genesis of crystal-rich rhyolite in a deeply dissected supervolcano in the Nevada Great Basin: source of the Late Eocene Caetano Tuff. J Petrol 57(8):1599-1644

Wendt I, Höhndorf A, Wendt JI, Müller P, Wetzel K (1995) Radiometric dating of volcanic rocks in NW Saxony by combined use of $\mathrm{U}-\mathrm{Pb}$ and $\mathrm{Sm}-\mathrm{Nd}$ zircon dating as well as $\mathrm{Sm}-\mathrm{Nd}$ and $\mathrm{Rb}-\mathrm{Sr}$ whole-rock and mineral systematics. Terra Nostra 1995, 7 (11th meeting on geodynamics of the European Variscides, 2nd. Symposium on Permocarboniferous Igneous Rocks), pp 147-148, Potsdam

Wetzel K, Gerstenberger H, Wand G, Wendt I (1995) Zur Geochemie der nordwestsächsischen Vulkanite. Z Geol Wiss 23(4):371-400
Willcock MAW, Cas RAF (2014) Primary welding and crystallisation textures preserved in the intra-caldera ignimbrites of the Permian Ora Formation, northern Italy: implications for deposit thermal state and cooling history. Bull Volcanol 76:819. https://doi.org/ 10.1007/s00445-014-0819-5

Willcock MAW, Cas RAF, Giordano G, Morelli C (2013) The eruption, pyroclastic flow behaviour, and caldera in-filling processes of the extremely large volume $\left(>1290 \mathrm{~km}^{3}\right)$, intra-to extra-caldera, Permian Ora (Ignimbrite) Formation, Southern Alps, Italy. J Volcanol Geotherm Res 265:102-126

Wilson CJN, Blake S, Charlier BLA, Sutton AN (2006) The $26.5 \mathrm{ka}$ Oruanui eruption, Taupo volcano, New Zealand: development, characteristics and evacuation of a large rhyolitic magma body. J Petrol 47(1):35-69

Wu CM, Chen HX (2015) Revised Ti-in-biotite geothermometer for ilmenite-or rutile-bearing crustal metapelites. Sci Bull 60(1):116-121 